Article

\title{
Inhibitory Effects of Novel 7-Substituted 6-iodo-3-O-Flavonol Glycosides against Cholinesterases and $\beta$-secretase Activities, and Evaluation for Potential Antioxidant Properties
}

\author{
Emmanuel N. Agbo ${ }^{1}$, Samantha Gildenhuys ${ }^{2, *(\mathbb{D})}$ and Malose J. Mphahlele ${ }^{1, *(1)}$ \\ 1 Department of Chemistry, College of Science, Engineering and Technology, University of South Africa, \\ Private Bag X06, Florida 1710, South Africa; piruesbest@yahoo.com \\ 2 Department of Life \& Consumer Sciences, College of Agriculture and Environmental Sciences, \\ University of South Africa, Private Bag X06, Florida 1710, South Africa \\ * Correspondence: gildes@unisa.ac.za (S.G.); mphahmj@unisa.ac.za (M.J.M.); \\ Tel.: +27-114713295 (S.G.); +27-116709301 (M.J.M.)
}

Received: 14 September 2019; Accepted: 24 September 2019; Published: 26 September 2019

\begin{abstract}
A series of 7-halogeno- $(\mathrm{X}=\mathrm{F}, \mathrm{Cl}, \mathrm{Br})$ and 7-methoxy-substituted acetylated 6-iodo-3-O-flavonol glycosides were prepared, and evaluated for inhibitory effect in vitro against acetylcholinesterase (AChE) and butyrylcholinesterase (BChE) activities. 7-Bromo-2-(4-chlorophenyl)-6-iodo-4H-chromen-4-one-3$O-2,3,4,6-O$-tetraacetyl- $\beta$ - $d$-glucopyranoside (2k) and 7-bromo-6-iodo-2-(4-methoxyphenyl)-4Hchromen-4-one-3-O-2,3,4,6-O-tetraacetyl- $\beta-d$-glucopyranoside (21) exhibited significant inhibitory effect against AChE activity when compared to the activity of the reference standard, donepezil. Compound 2k was found to be selective against $\mathrm{AChE}$ and to exhibit reduced inhibitory effect against BChE activity. 6-Iodo-7-methoxy-2-(4-methoxyphenyl)-4H-chromen-4-one-3-O-2,3,4,6-Otetraacetyl- $\beta$ - $d$-glucopyranoside ( $2 \mathbf{p}$ ) was found to exhibit increased activity against $\mathrm{BChE}$, more so than the activity of donepezil. The most active compounds were also evaluated for inhibitory effect against $\beta$-secretase activity and for potential radical scavenging activities. The experimental data were complemented with molecular docking (in silico) studies of the most active compounds into the active sites of these enzymes.
\end{abstract}

Keywords: 3-O-flavonol glycosides; X-ray; acetylcholinesterase; butyrylcholinesterase; $\beta$-secretase; kinetic studies; molecular docking; antioxidant assay

\section{Introduction}

Alzheimer's disease (AD) is a chronic neurodegenerative disease, which is characterized by progressive loss of memory, cognitive impairment or inability to learn, and abnormal behavior [1]. The disease affects elderly people throughout the world and it usually starts slowly and worsens over time. It has also been found that the efficiency of the brain's antioxidant system gradually decreases with age, and this is more so in AD patients [2]. Several molecular mechanisms of AD have been proposed, including the cholinergic hypothesis, $\beta$-amyloid cascade, oxidative stress, and metal imbalance [3]. Strategies currently pursued for the treatment of AD include inhibition of cholinesterases and targeting amyloid- $\beta(\mathrm{A} \beta)$ peptides as well as metal-A $\beta$ complexes [4]. However, the pathogenesis of AD is far more complex with other mechanisms, with inflammation [5] and immune suppression [6] also implicated. The brains of patients suffering from AD, on the other hand, are characterized by significant oxidative damage associated with the abnormal marked accumulation of $A \beta$ and the deposition of neurofibrillary tangles [7]. This has led to a growing debate for the inclusion of 
antioxidants as supplements in the standard therapy for AD [8]. However, a single multi-target drug may have distinctive advantages over drug-combination therapies for the treatment of a multi-factorial disease such as AD. This multi-target-directed ligand (MTDL) design strategy has been found to be more effective for the treatment of AD than the one-target-one drug concept and drug-combination therapies [9-11]. Moreover, MTDLs reduce the risk of poor patient compliance, drug-drug interactions, and pharmacokinetic differences between the individual drugs. It is evident that the treatment of AD could benefit from the use of multipotent drugs that present cholinesterases and $\beta$-secretase inhibitory activities as well as free-radical scavenging properties.

Plant-derived flavonoid-rich foods or supplements are envisaged to delay the initiation or slow the progression of AD and related neurodegenerative disorders [12]. Certain flavonols and flavones have been reported to act as $\beta$-secretase inhibitors and to suppress $\beta$-secretase expression [13]. Moreover, these flavonoids have been proven to be powerful antioxidants [14]. Flavonols exist predominantly in nature as the flavonol-3-O-glycosides. The sugar moiety affects the function, structure, and stability of cells and enzymes [15]. Glycosylation of quercetin to generate quercetin-3-O-glucoside, for example, has been found to prevent degradation of the flavonol scaffold and to increase biological activity [16]. The presence of halogen atom/s in a molecule has been found to increase the membrane permeability and prolongs the lifetime of the drug [17]. Moreover, the strong electron-withdrawing effect of the halogen atoms has been found to facilitate formation of hydrogen and/or halogen bonds that help to stabilize interactions of drug molecules with the protein targets [18-20]. A series of acetylated 3-O-flavonol glycosides was prepared before and their structure activity relationship for anticholinesterase effect evaluated with respect to the nature and pattern of the substituent on the B-ring [21]. Since no halogenated flavonoid glycosides exist in nature and are inspired by the MTDL strategy, a sugar moiety was appended onto the known 7-halogeno- $(\mathrm{X}=\mathrm{F}, \mathrm{Cl}, \mathrm{Br})$ and 7-methoxy-substituted 6-iodoflavonols [22]. The prepared halogenated 3-O-flavonol glycosides were evaluated through enzymatic assays in vitro for their potential to inhibit acetylcholinesterase (AChE) and butyrylcholinesterase (BChE) activities. Moreover, the most active compounds against these enzymes were evaluated for inhibitory potential against $\beta$-secretase and for antioxidant activity in the 2,2-diphenyl-1-picrylhydrazyl (DPPH) radical scavenging activity assay. Molecular docking (in silico) studies into the active sites of $\mathrm{AChE}, \mathrm{BChE}$, and $\beta$-secretase were performed on the most active compounds against these enzymes to rationalize the hypothetical protein-ligand binding interactions.

\section{Results and Discussion}

\subsection{Chemistry}

The route used for the synthesis of the title compounds is outlined in Scheme 1 and it involved subjecting the known flavonols 1a-1p [22] to glycosylation with acetobromo- $\alpha$-D-glucose. The acylated 3-O-glycosides $\mathbf{2 a - 2 p}$ (see Table 1 for the substitution pattern of these compounds) were purified by column chromatography on silica gel and then characterized using a combination of nuclear magnetic resonance (NMR), infrared (IR,) and mass spectrometric techniques. Their ${ }^{1} \mathrm{H}-\mathrm{NMR}$ spectra revealed the presence of signals in the aromatic region and additional peaks in the aliphatic region $\delta 3.60-5.70 \mathrm{ppm}$ with two intense signals around $\delta 1.99 \mathrm{ppm}$ and $\delta 2.02 \mathrm{ppm}$ corresponding to the non-equivalent acetyl groups of the incorporated acylated sugar moiety. Moreover, their ${ }^{13} \mathrm{C}-\mathrm{NMR}$ spectra also revealed two characteristic signals around $\delta 173 \mathrm{ppm}$ and $\delta 170 \mathrm{ppm}$ corresponding to the 4-carbonyl and acetyl groups, respectively. Their IR spectra, on the other hand, lacked the absorption band for the 3-hydroxyl group and revealed the presence of additional carbonyl band around $v_{\max }$ $1720 \mathrm{~cm}^{-1}$ for the acyl groups. The molecular masses of these compounds were confirmed by electron spray ionization mass spectrometry and these complementary spectroscopic techniques corroborated the assigned structures. Replacement of the 3-hydroxyl group with the acetylated 3-O-glycoside function on the flavone framework is, in fact, evident in the single crystal X-ray diffraction structure of compound $\mathbf{2 g}$ shown in Figure 1 [23]. 


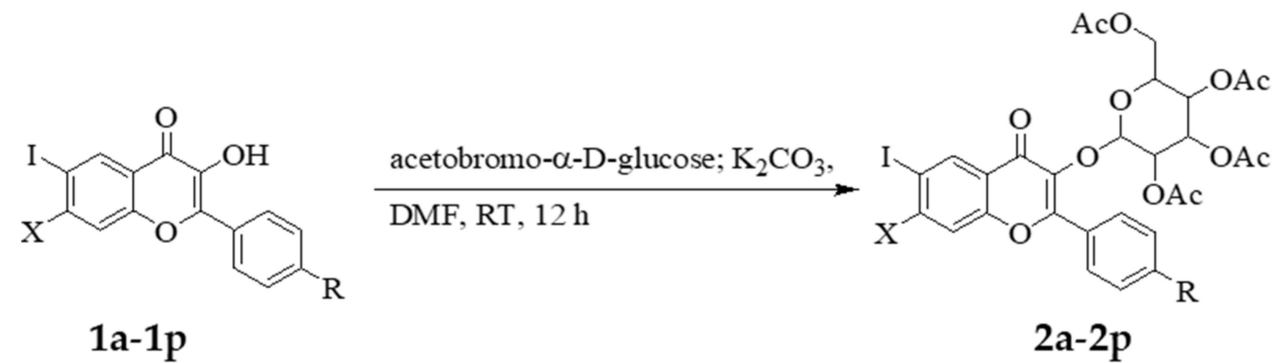

Scheme 1. Synthesis of the 7-substituted 6-iodo-3-O-flavonol glycosides $\mathbf{2 a - 2} \mathbf{p}$.

Table 1. Substitution pattern for compounds $2 \mathbf{a}-\mathbf{2} \mathbf{p}$.

\begin{tabular}{|c|c|c|c|c|}
\hline \multirow{2}{*}{$\frac{\mathbf{R}}{\mathrm{H}}$} & \multicolumn{4}{|c|}{ Designation of $X$ for $2 a-2 p$} \\
\hline & $\mathrm{F}(\mathbf{2 a})$ & $\mathrm{Cl}(\mathbf{2 e})$ & $\operatorname{Br}(2 \mathbf{i})$ & $\mathrm{OCH}_{3}(2 \mathrm{~m})$ \\
\hline $\mathrm{F}$ & $F(2 b)$ & $\mathrm{Cl}(\mathbf{2 f})$ & $\operatorname{Br}(2 \mathbf{j})$ & $\mathrm{OCH}_{3}(\mathbf{2 n})$ \\
\hline $\mathrm{Cl}$ & $\mathrm{F}(2 \mathrm{c})$ & $\mathrm{Cl}(\mathbf{2 g})$ & $\operatorname{Br}(2 \mathbf{k})$ & $\mathrm{OCH}_{3}(\mathbf{2 o})$ \\
\hline $\mathrm{OCH}_{3}$ & $\mathrm{~F}(2 \mathrm{~d})$ & $\mathrm{Cl}(\mathbf{2 h})$ & $\operatorname{Br}(21)$ & $\mathrm{OCH}_{3}(2 \mathbf{p})$ \\
\hline
\end{tabular}

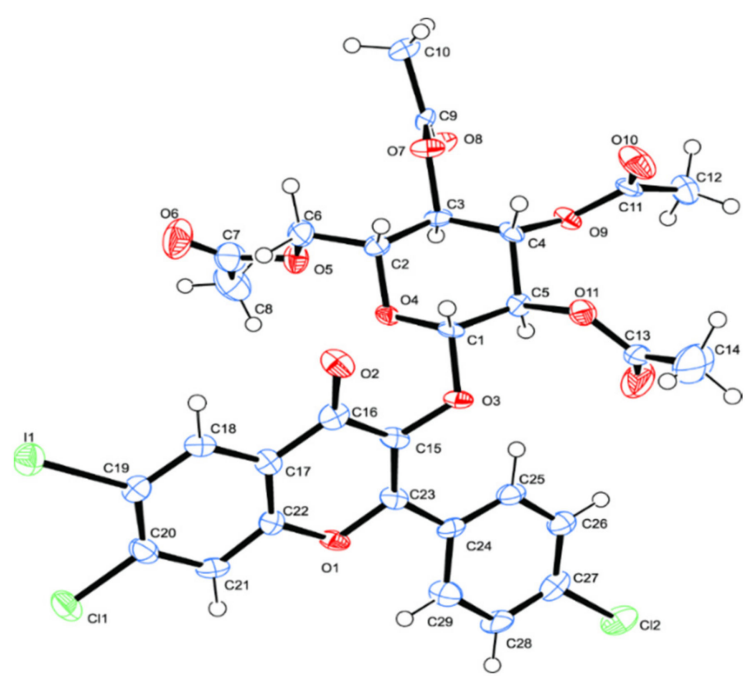

Figure 1. Oak Ridge Thermal Ellipsoid Plot (ORTEP) diagram (50\% probability level) of $\mathbf{2 g}$.

Compounds $\mathbf{2 a} \mathbf{a} \mathbf{2} \mathbf{p}$ were in turn, evaluated for potential biological properties as inhibitors of cholinesterase (AChE and/or BChE) and $\beta$-secretase (BACE-1) activities.

\subsection{Inhibitory Activity of the 3-O-flavonol Glycosides Against AChE, BChE, and $\beta$-Secretase}

Despite an increase in the use of drugs for receptors to modulate signals from outside the cell, $47 \%$ of all current drugs have been found to inhibit enzyme targets [24]. As a result, enzymes remain the primary targets for drug design because altering the activity of an enzyme has immediate and defined effects. Consequently, the 7-substituted 6-iodo-3-O-flavonol glycosides $\mathbf{2 a - 2 p}$ were evaluated for inhibitory effect against acetylcholinesterase (AChE) and butyrylcholinesterase (BChE) activity using the known non-competitive reversible $\mathrm{AChE}$ inhibitor, donepezil, as a reference standard. Compounds $\mathbf{2 a}-\mathbf{2} \mathbf{p}$ have been grouped into four series, namely $\mathbf{2 a}-\mathbf{2} \mathbf{d}(\mathrm{X}=\mathrm{F}), \mathbf{2} \mathbf{e}-\mathbf{2 h}(\mathrm{h}=\mathrm{Cl}), \mathbf{2} \mathbf{i}-\mathbf{2 l}(\mathrm{l}=\mathrm{Br})$ and $2 \mathbf{m}-\mathbf{2} \mathbf{p}\left(\mathrm{X}=\mathrm{OCH}_{3}\right)$ with the 2-aryl substituent representing $\mathrm{C}_{6} \mathrm{H}_{5^{-}}, 4-\mathrm{FC}_{6} \mathrm{H}_{4^{-}}, 4-\mathrm{ClC}_{6} \mathrm{H}_{4^{-}}$, and $4-\mathrm{MeOC}_{6} \mathrm{H}_{4}-$, respectively (Table 2). The structure activity relationship (SAR) of these compounds has been rationalized with respect to the nature of substituent on the 2-phenyl substituent and the 7-position of the chromenone (flavone) moiety. The effect of $O$-glycoside moiety, on the other hand, has been rationalized by comparison with the previously published data of the corresponding flavonol precursors $1 \mathbf{a}-\mathbf{1 p}$ [22]. A combination of fluorine atom at position-7 of the flavone skeleton with $O$-glycoside 
moiety in compounds $\mathbf{2 a - 2 d}$ resulted in reduced or lack of inhibitory effect against both AChE and BChE activities. Significantly reduced inhibitory effect was observed for $2 \mathbf{b}\left(\mathrm{IC}_{50}=28.2 \pm 0.02 \mu \mathrm{M}\right)$ and $2 \mathrm{c}$ $\left(\mathrm{IC}_{50}=24.74 \mu \mathrm{M}\right)$ against $\mathrm{AChE}$ activity. The corresponding flavonol precursors $\mathbf{1 b}\left(\mathrm{IC}_{50}=3.23 \mu \mathrm{M}\right)$ and 1c $\left(\mathrm{IC}_{50}=3.35 \mu \mathrm{M}\right)$, on the other hand, have previously been found to exhibit increased inhibitory effect against this enzyme, more so than donepezil $\left(\mathrm{IC}_{50}=4.77 \mu \mathrm{M}\right)$ at the same concentration [22]. Reduced inhibitory effect against AChE activity has also been observed for the 7-chloro substituted derivatives $\mathbf{2 e}-\mathbf{2 h}$ though these compounds were moderately inhibiting against BChE activity when compared to the activity of donepezil $\left(\mathrm{IC}_{50}=4.82 \mu \mathrm{M}\right)$. A combination of 7-chloro and 2-(4-chlorophenyl)- group in the flavonol-3-O-glycoside $\mathbf{2 g}$, for example, resulted in significant inhibitory effect against BChE activity with $\mathrm{IC}_{50}$ value of $7.15 \mu \mathrm{M}$ compared to the activity of donepezil. The activity of compound $2 \mathrm{~g}$ against the two enzymes was found to be comparable to the activity of the parent flavonol $\mathbf{1 g}$, which was previously found to exhibit reduced inhibitory effect against $\mathrm{AChE}\left(\mathrm{IC}_{50}=59.10 \mu \mathrm{M}\right)$ and significant activity against $\mathrm{BChE}\left(\mathrm{IC}_{50}=7.69 \mu \mathrm{M}\right)$ [22]. The presence of 3-O-glycoside moiety in $\mathbf{2 h}$, on the other hand, resulted in significantly reduced inhibitory effect against $\mathrm{BChE}$ activity $\left(\mathrm{IC}_{50}=10.10 \mu \mathrm{M}\right)$ when compared to the activity of the corresponding substrate $\mathbf{1 h}\left(\mathrm{IC}_{50}=5.72 \mu \mathrm{M}\right)$ [22]. The presence of bromine atom at position-7 resulted in moderate to increased inhibitory effect against AChE activity for compounds $\mathbf{2 i - 2 1 . ~ W i t h i n ~ t h i s ~ s e r i e s ~ o f ~ c o m p o u n d s , ~ t h e ~ t r e n d ~ i n ~ a c t i v i t y ~ i n c r e a s e s ~ w i t h ~ i n c r e a s i n g ~}$ size of the substituent at the para position of the 2-phenyl ring, $\mathrm{H}<\mathrm{F}<\mathrm{Cl}<\mathrm{OCH}_{3}$, and is in the order $70.56(\mathbf{2} \mathbf{i})<31.20(\mathbf{2} \mathbf{j})<5.18(\mathbf{2 k})<5.05 \mu \mathrm{M}(\mathbf{2} \mathbf{l})$. Hitherto, the size of the 2-aryl substituent showed an opposite effect on the anti-acetylcholinesterase activity of the corresponding substrates 1i-11 [22]. A combination of 7-bromo and either 2-(4-chlorophenyl)- group in 2k or a 2-(4-methoxyphenyl)- group in 21 resulted in significant inhibitory effect against AChE activity than any of the compounds tested in this investigation. Compound $\mathbf{2 k}$ seems to be selective towards AChE since it displayed reduced anti-BChE activity. Compound 21, on the other hand, appears to exhibit dual activity against both enzymes, though more so for $\mathrm{AChE}\left(\mathrm{IC}_{50}=5.05 \mu \mathrm{M}\right)$ than $\mathrm{BChE}\left(\mathrm{IC}_{50}=7.24 \mu \mathrm{M}\right)$ when compared to donepezil with $\mathrm{IC}_{50}$ values of 4.82 and $6.01 \mu \mathrm{M}$, respectively. The corresponding 3-flavonol precursors $1 \mathbf{k}$ and $\mathbf{1 1}$ were previously found to exhibit reduced inhibitory effect against the AChE activity (IC 50 values of 29.4 and $28.99 \mu \mathrm{M}$, respectively), but increased inhibitory effect against BChE activity (5.25 and $4.88 \mu \mathrm{M}$, respectively) [22]. Within the series $\mathbf{2} \mathbf{i}-\mathbf{2} \mathbf{1}$, only compounds $\mathbf{2} \mathbf{i}$ and $\mathbf{2} \mathbf{l}$ exhibited significant inhibitory effect against BChE activity. The presence of a halogen atom at the para position of the 2-aryl group of flavones $\mathbf{2} \mathbf{j}$ and $\mathbf{2 k}$, on the other hand, resulted in significantly reduced activity against this enzyme. For the series $\mathbf{2 m}-\mathbf{2}$ p substituted with a strongly pi-electron donating and lipophilic methoxy group at the 7-position, significant inhibitory effect against AChE activity was observed for derivatives $2 \mathbf{n}$ and 2 p substituted with a 2-(4-fluorophenyl)- and 2-(4-methoxyphenyl)- group with $\mathrm{IC}_{50}$ values of 6.33 and $9.19 \mu \mathrm{M}$, respectively. The 2-(4-methoxyphenyl)-substituted derivative $2 \mathrm{p}$ seems to exhibit dual activity against both enzymes, more so against $\mathrm{BChE}\left(\mathrm{IC}_{50}=5.21 \mu \mathrm{M}\right)$ than $\mathrm{AChE}\left(\mathrm{IC}_{50}=9.19 \mu \mathrm{M}\right)$. Hitherto, the corresponding substrate 1p was found to exhibit significant inhibitory effect against $\mathrm{AChE}\left(\mathrm{IC}_{50}=7.19 \mu \mathrm{M}\right)$ and $\mathrm{BChE}\left(\mathrm{IC}_{50}=3.29 \mu \mathrm{M}\right)$ activities [22]. The modest selectivity values for compounds $\mathbf{2 l}$ and $\mathbf{2 p}$ (Table 2) may make these compounds potential dual inhibitors against AChE and BChE activities. Dual inhibition of AChE and BChE has become an efficient strategy to alleviate Alzheimer's disease symptoms with minimal or no side effects [25]. 
Table 2. AChE and BChE inhibitory activities of flavonols $\mathbf{2 a - 2} \mathbf{p}$.

\begin{tabular}{ccccc}
\hline \multirow{2}{*}{ Compound } & \multicolumn{2}{c}{ IC $_{\mathbf{5 0}}(\boldsymbol{\mu M} \mathbf{M})$} & SI \\
\cline { 2 - 5 } & AChE & BChE & BChE/AChE & AChE/BChE \\
\hline $\mathbf{2 a}$ & $18.72 \pm 0.03$ & $26.17 \pm 0.01$ & 1.40 & 0.71 \\
$\mathbf{2 b}$ & $28.2 \pm 0.02$ & $21.9 \pm 0.04$ & 0.78 & 1.3 \\
$\mathbf{2} \mathbf{c}$ & $24.74 \pm 0.03$ & $30.84 \pm 0.04$ & 1.25 & 0.80 \\
$\mathbf{2} \mathbf{2}$ & $60.40 \pm 0.05$ & $19.25 \pm 0.11$ & 0.32 & 3.13 \\
$\mathbf{2}$ & $34.44 \pm 0.03$ & $9.03 \pm 0.12$ & 0.26 & 2.85 \\
$\mathbf{2} \mathbf{f}$ & $70.66 \pm 0.01$ & $31.09 \pm 0.04$ & 0.44 & 4.35 \\
$\mathbf{2}$ & $31.44 \pm 0.13$ & $7.15 \pm 0.01$ & 0.23 & 2.56 \\
$\mathbf{2 h}$ & $25.92 \pm 0.02$ & $10.10 \pm 0.06$ & 0.39 & 7.14 \\
$\mathbf{2} \mathbf{2}$ & $70.56 \pm 0.03$ & $9.79 \pm 0.04$ & 0.14 & 0.76 \\
$\mathbf{2}$ & $31.20 \pm 0.05$ & $40.93 \pm 0.04$ & 1.31 & 0.17 \\
$\mathbf{2}$ & $5.18 \pm 0.01$ & $29.95 \pm 0.02$ & 5.78 & 0.70 \\
$\mathbf{2}$ & $5.05 \pm 0.02$ & $7.24 \pm 0.03$ & 1.43 & 1.89 \\
$\mathbf{2}$ & $56.21 \pm 0.01$ & $29.80 \pm 0.06$ & 0.53 & 0.18 \\
$\mathbf{2} \mathbf{2}$ & $6.23 \pm 0.05$ & $34.21 \pm 0.02$ & 5.49 & 0.78 \\
$\mathbf{2 0}$ & $28.12 \pm 0.06$ & $36.10 \pm 0.02$ & 1.28 & 1.75 \\
$\mathbf{2} \mathbf{p}$ & $9.19 \pm 0.03$ & $5.21 \pm 0.03$ & 0.57 & 0.80 \\
\hline
\end{tabular}

The values are given as mean \pm standard deviation $(\mathrm{SD})$ in three independent experiments. Selectivity Index (SI): the $\mathrm{AChE}$ selectivity index is defined as $\mathrm{IC}_{50}(\mathrm{BChE}) / \mathrm{IC} \mathrm{C}_{50}(\mathrm{AChE})$ and that of $\mathrm{BChE}$ as $\mathrm{IC}_{50}(\mathrm{AChE}) / \mathrm{IC} \mathrm{C}_{50}(\mathrm{BChE})$ affinity ratios.

High levels of $\mathrm{AChE}$ or $\mathrm{BChE}$ have been found to have a role in amyloid beta(A $\beta)$-peptide aggregation during the early stages of senile plaque formation as well as in other pathological characteristics of $\mathrm{AD}[26,27]$. $\beta$-Site amyloid precursor protein (APP) cleaving enzyme 1 (BACE-1) plays a significant role in the cleavage of amyloid precursor protein, which leads to the production of $\alpha, \beta$-peptide [28]. Overproduction of $A \beta$ by $\beta$-secretase results in toxic fibrils causing neurodegeneration characteristic of the Alzheimer's disease [29]. $\beta$-Secretase is considered the initial and rate-limiting step in $A \beta$ production, which makes it another target for the treatment and prevention of AD. Certain flavonols and flavones have been reported to act as $\beta$-secretase inhibitors and to suppress $\beta$-secretase expression [13]. With the aim to discover compounds that could target different pathological features of the Alzheimer's disease, we decided to evaluate compounds $2 \mathbf{l}$ and $2 \mathbf{p}$ with potential dual inhibitory effect against $\mathrm{AChE}$ and $\mathrm{BChE}$ activities for inhibitory effect against $\beta$-secretase activity. Quercetin has been employed as a reference standard for this assay because it has previously showed significant inhibitory effect against $\beta$-secretase and reduced the levels of $A \beta$ in neurons [30]. Compounds 21 and $2 \mathbf{p}$ were found to be moderately inhibiting against $\beta$-secretase activity when compared to quercetin $\left(\mathrm{IC}_{50}=13.7 \mu \mathrm{M}\right.$ ) with $\mathrm{IC}_{50}$ values of $18.3 \mu \mathrm{M}$ and $25.2 \mu \mathrm{M}$, respectively (Table 3). The inhibitory effect of these compounds against $\beta$-secretase activity are slightly higher than those previously observed for the corresponding flavonol precursors $11\left(\mathrm{IC}_{50}=15.74 \mu \mathrm{M}\right)$ and $1 \mathbf{p}\left(\mathrm{IC}_{50}=22.44 \mu \mathrm{M}\right)$. Compounds 11 and $1 \mathbf{p}$ were previously found to be less inhibiting against this enzyme when compared to quercetin [22].

Table 3. Inhibitory activity of compounds 21 and $2 \mathbf{p}$.

\begin{tabular}{cc}
\hline Compounds & $\mathrm{IC}_{\mathbf{5 0}}(\boldsymbol{\mu M})$ \\
\hline $\mathbf{2 1}$ & $18.3 \pm 0.01$ \\
$\mathbf{2 p}$ & $25.2 \pm 0.15$ \\
Quercetin & $13.7 \pm 0.02$ \\
\hline
\end{tabular}

Since some of the glycosides retain the potent and selective cholinesterase and $\beta$-secretase inhibitory activity of the parent 3-flavonols, we decided to elucidate their plausible mechanisms of 
inhibition. Based on the in vitro results of $\mathrm{ChE}$ and $\beta$-secretase inhibition, the kinetic study was carried on compounds 21 and $2 p$ as described below.

\subsection{Kinetic Studies Against Cholinesterases and $\beta$-Secretase}

Compounds 21 and $\mathbf{2 p}$ were subjected to kinetic studies at increasing concentrations $(0.1,0.5$, 2.5 and $5.0 \mu \mathrm{M}$ ) of the substrates, acetylthiocholine iodide (ATChI) and butyrylthiocholine iodide (BTChI), respectively. The Lineweaver-Burk plots were drawn to determine the type of inhibition these compounds display against $\mathrm{AChE}$ and BChE (refer to Figure S2. In the Supplementary Material for the corresponding graphs). For compound $\mathbf{2 l}$ there is a decrease in the Vmax as the inhibitor concentration is increased ( 0.054 to 0.018$)$ while the $\mathrm{Km}$ remains relatively unchanged $(0.16 \pm 0.02 \mu \mathrm{M})$. This would indicate that $\mathbf{2 l}$ inhibits the enzyme in a non-competitive manner binding to the enzyme and still allowing the substrate to bind. Analysis of the Lineweaver-Burk plot for $2 \mathrm{p}$ also indicates non-competitive inhibition as there is a decrease in the Vmax of AChE (0.033 to 0.015 for 0 to $5 \mu \mathrm{M}$ of $2 \mathrm{p}$, respectively) while $\mathrm{Km}$ remains relatively unaffected $0.13 \pm 0.03 \mu \mathrm{M}$ with increasing inhibitor concentrations ( 0 to $5 \mu \mathrm{M} 2 \mathrm{p}$ ). Both compounds seem to display non-competitive inhibition towards BChE. The Vmax values for 21 decrease from 0.064 to 0.017 while $\mathrm{Km}$ remains unchanged $(0.19 \pm 0.03 \mu \mathrm{M})$ with increasing inhibitor concentrations from 0 to $5 \mu \mathrm{M}$. Similarly for $2 p$ the Vmax values decrease from 0.057 to 0.016 while $\mathrm{Km}$ remains unchanged $(0.22 \pm 0.01 \mu \mathrm{M})$ with increasing inhibitor concentrations from 0 to $5 \mu \mathrm{M}$. Dixon plots for $\mathbf{2 l}$ and $\mathbf{2 p}$ against both AChE and BChE were used to determine the Ki or inhibition constant values for the two compounds (see Figure S2 in the Supplementary Material). The inhibition constants (Ki) against AChE were determined to be $1.38 \pm 0.62$ and $2.36 \pm 0.32$ for compounds 21 and $2 \mathbf{p}$, respectively. Ki values for compounds 21 and 2 p against BChE were calculated to be $1.51 \pm 0.04$ and $1.62 \pm 0.03$, respectively. Kinetic studies were also conducted to determine the mode of inhibition exhibited by compounds $2 \mathbf{l}$ and $\mathbf{2 p}$ against $\beta$-secretase (refer to Figure S3 in the Supplementary Material). Based on Lineweaver-Burk plots and resulting $\mathrm{Km}$ and Vmax values compound $\mathbf{2 l}$ displays non-competitive inhibition with unchanged $\mathrm{Km}$ values $(0.20 \pm 0.1)$ in the absence and presence of increasing inhibitor concentration while the Vmax values decrease from 0.04 to 0.02 . Similarly for $2 \mathbf{p}$, the $\mathrm{Km}$ values remain relatively unchanged $(3.6 \pm 0.2 \mu \mathrm{M})$ while Vmax decreases from 0.09 in the absence of inhibitor to 0.02 in the presence of $5 \mu \mathrm{M}$ inhibitor. Therefore, $2 \mathrm{p}$ displays non-competitive inhibition of $\beta$-secretase. Ki values obtained from Dixon plots for the inhibition of $\beta$-secretase by $2 \mathbf{l}$ and $2 \mathbf{p}$ were calculated to be $2.42 \pm 0.05$ and $2.94 \pm 0.02$, respectively.

\subsection{Molecular Docking Studies into AChE, BChE and $\beta$-Secretase Active Sites}

To rationalize the SAR and establish plausible protein-ligand interactions at molecular level, we docked the most active compounds into the active pockets of AChE (compounds 2k, 21, 2n, and $2 \mathrm{p}$ ), BChE (compounds $\mathbf{2 e}, \mathbf{2 g}, \mathbf{2 l}$ and $\mathbf{2 p}$ ) and $\beta$-secretase (compounds $\mathbf{2 l}$ and $\mathbf{2 p}$ ).

\subsubsection{Molecular Docking Studies of Compounds 2k, 21, 2n, and 2p into AChE Active Sites}

Compounds $\mathbf{2 k}, \mathbf{2} \mathbf{1}, \mathbf{2 n}$, and $\mathbf{2 p}$ were docked into the active pockets AChE against donepezil (Figure 2a,b), which is known to interact with both the catalytic active site (CAS) and the peripheral anionic site (PAS) tryptophans via ring-stacking interactions [31].

Figure 3 shows the docking poses of compounds $\mathbf{2 k}, \mathbf{2 1}, \mathbf{2 n}$, and $\mathbf{2 p}$ into AChE active sites. The flavone framework of compound 2k (Figure 3a) is involved in pi-pi stacking and pi-pi T-shaped interactions with the protein residues Trp84, Trp279, Tyr334, Phe330, and Phe331. Similar interactions are predicted between the flavone moiety of $\mathbf{2 l}$ (Figure 3b) and the protein residues Tyr334, Phe330, and Phe331. Chlorine atom of $\mathbf{2 k}$ is involved in alkyl and pi-alkyl interactions with the protein residues Phe330, Trp84, and His440, whereas its iodine atoms exhibits similar interactions with Trp279. Molecular docking predicts several hydrogen bond interactions between the glycoside moiety of $2 \mathbf{k}$ and the protein residues Tyr121, Tyr130, Gly118 and Gly119 as well as histidine-440 (His440, Hb 
distance $=2.19 \AA$ ) of the catalytic triad. Compound $2 \mathbf{l}$, on the other hand, is involved in hydrogen bond interactions with Asp72, Tyr121 and Gly123 as well as His440 (Hb distance $=2.20 \AA$ A . Additional alkyl and pi-alkyl interactions are predicted between the methoxy group of $\mathbf{2 l}$ and the protein residues Trp233, Ala201, Phe290 and His440. Both molecules seem to penetrate the aromatic cleft of the AChE through chromone scaffold and their entrance into the aromatic cleft is supported by pi-pi interaction with phenylalanine (Phe330) in the acyl binding pocket. The observed slight increase in inhibitory effect of $\mathbf{2 l}$ against AChE activity is presumably due to the increased lipophilicity of the methoxy group, which seems to interact with more protein residues than chlorine atom of $\mathbf{2 k}$. The flavone framework of $\mathbf{2 n}$ (Figure 3c), on the other hand, is involved in pi-pi stacking and pi-pi T-shaped interactions with Tyr334, Trp279, and Phe331. Pi-lone-pair interaction is predicted between ring-C and the protein residue, Tyr121. Hydrogen bond interactions are predicted between the glycoside arm and the protein residues Gly118 and His440. Gly118 and Gly119 are also involved in hydrogen bonding with the methoxy group of the 2-aryl substituent. These increased interactions probably account for the significant inhibitory effect of this compound against $\mathrm{AChE}$ activity $\left(\mathrm{IC}_{50}=6.33 \mu \mathrm{M}\right)$. The flavone framework, iodine atom and the methoxy group of compound $\mathbf{2} \mathbf{p}$ (Figure $3 \mathrm{~d}$ ), are involved in hydrophobic interactions with several protein residues. Hydrogen bond interactions are predicted between the glycoside moiety and the protein residues Tyr130 and His440.

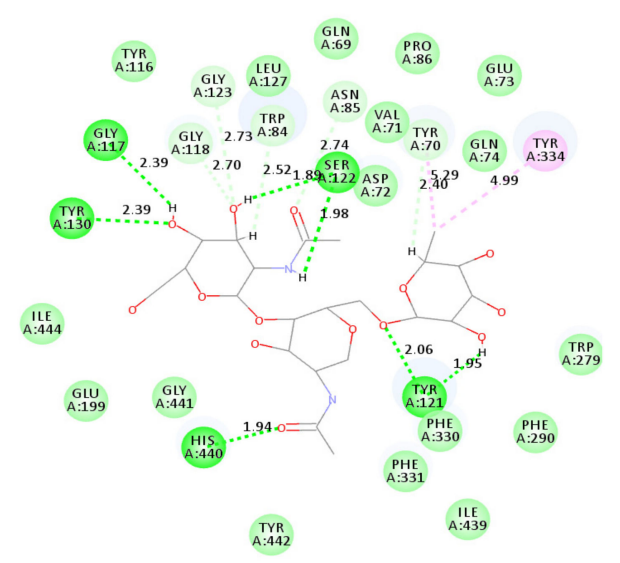

(a)

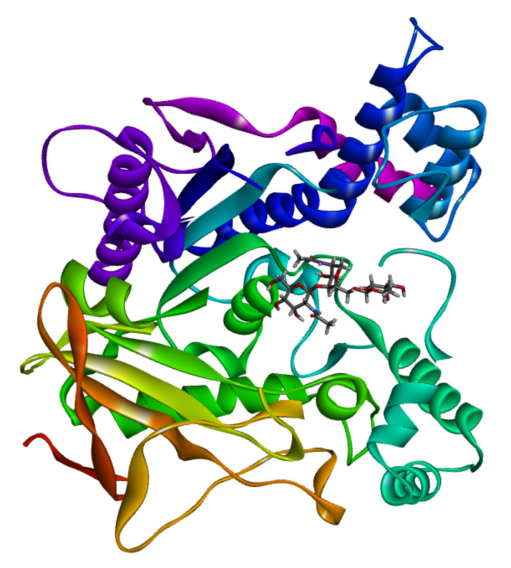

(b)

Figure 2. Docking pose of donepezil (a \& b) with AChE (Protein Data Bank (PDB): 1GQR). Interactions are color coded: bright green represents conventional hydrogen bonds; light green: van der Waals interactions; very light green: carbon hydrogen bonds; dark pink: pi-pi interactions; and light pink: pi-alkyl and alkyl interactions.

Compounds $\mathbf{2 k}, \mathbf{2 l}, \mathbf{2 n}$, and $2 \mathrm{p}$ are predicted to have hydrophobic interactions with protein residues Trp279 and Trp334 in the PAS of AChE, and noncovalent interactions (hydrogen bonding, van der Waals interactions and pi stacking, etc.) with His440 of the catalytic triad. These interactions which involve both the flavone scaffold and the glycoside wing probably account for the observed increased inhibitory effect of the compounds against the AChE activity. The predicted interactions of these compounds with protein residues in the CAS and PAS indicate that binding can take place at the active site of these enzymes. The active site cleft is large, and the non-competitive mode of inhibition displayed by compounds $2 \mathbf{l}$ and $2 \mathbf{p}$ would indicate that their binding does no exclude substrate binding at the active sites. The binding presumably affects the enzyme's activity by altering its conformation and affecting its catalytic activity. 




(a)

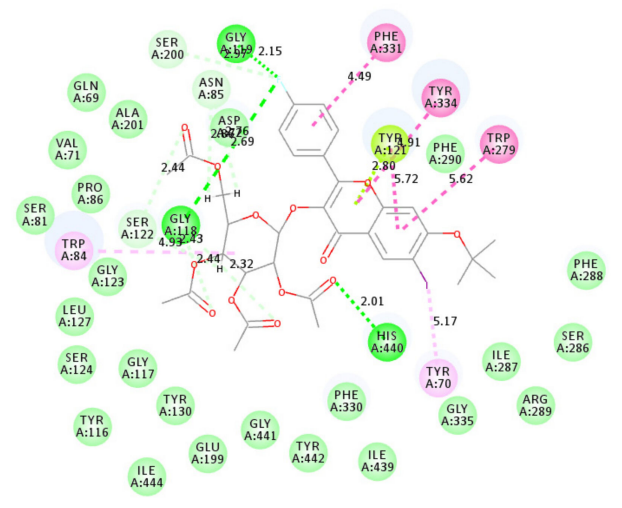

(c)

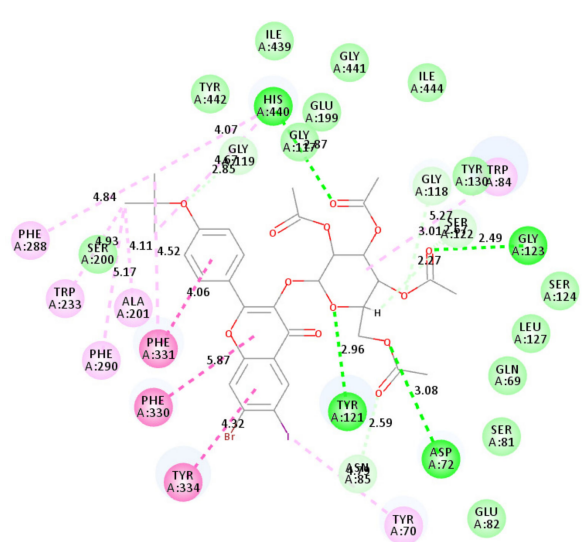

(b)

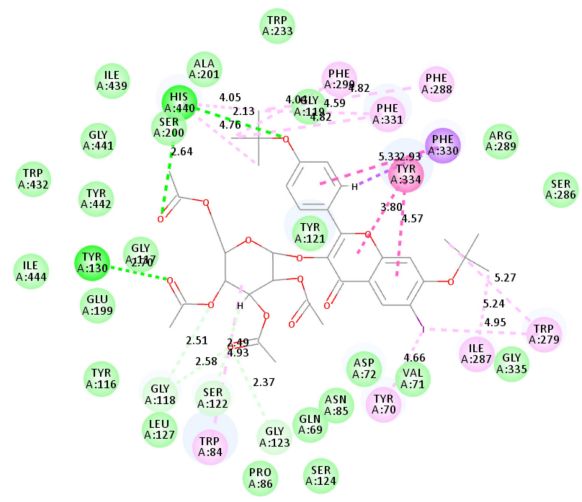

(d)

Figure 3. Docking poses of $\mathbf{2 k}(\mathbf{a}), 2 \mathbf{l}(\mathbf{b}), \mathbf{2 n}(\mathbf{c})$, and $\mathbf{2 p}(\mathbf{d})$ into AChE. Bright green represents conventional hydrogen bonds; light green: van der Waals interactions; very light green: carbon hydrogen bonds; dark pink: pi-pi interactions; light pink: pi-alkyl interactions; purple: pi-sigma interactions; and green yellow: pi-lone-pair interactions.

\subsubsection{Molecular Docking Studies of $\mathbf{2 e}, \mathbf{2} \mathbf{g}$, 21, and $\mathbf{2 p}$ into BChE Active Sites}

The docking poses of compounds $\mathbf{2 e}, \mathbf{2 g}$, 2l, and $\mathbf{2 p}$ into BChE active sites (Protein Data Bank (PDB): 1P0I) are represented in Figure 4. Weak van der Waals and carbon hydrogen bond interactions exist between the glycoside ring of compound 2e (Figure 4a) with Gly116 and Thr120. Ring-A and ring-B of this compound are involved in pi-pi and amide-pi interaction with Ile69 and Tyr332, respectively. Its C-ring, on the other hand, is involved in pi-anion interaction with Asp70, while pi-alkyl interaction is predicted between ring-B and Ala328. Hydrogen bond interactions are predicted to exist between the carbonyl oxygen atoms of the acetoxy groups of the glycoside fragment with Gly117, Glu197, Tyr128, and His438. These increased interactions presumably account for the observed moderate inhibitory effect of $\mathbf{2 e}$ against the BChE activity. Chlorine atom on ring-B of $\mathbf{2 g}$ (Figure $4 \mathbf{b}$ ) is involved in halogen bonding with Trp82 at the choline-binding site and there is also pi-anion interaction between this ring and Asp70. Alkyl and pi-alkyl interactions exist between chlorine and Pro84, and between iodine and Pro285 as well as between the glycoside ring and Phe329. There are several hydrogen bond interactions involving the glycoside moiety and the protein residues Gly116, Gly117, Glu197, and His438. Additional interactions of the 4-chlorophenyl group with Trp82 and Asp70 via halogen bonding and pi-anion interaction presumably account for the observed increased inhibitory effect of $2 \mathbf{g}\left(\mathrm{IC}_{50}=7.15 \mu \mathrm{M}\right)$ compared to $2 \mathbf{e}\left(\mathrm{IC}_{50}=9.03 \mu \mathrm{M}\right)$. The lipophilic 2-(4-methoxyphenyl) group of the most active compound $\mathbf{2 l}$ (Figure $4 \mathrm{c}$ ) against AChE activity is involved in alkyl and pi-alkyl interactions with several protein residues. Tyr332 is involved in pi-pi stacking interaction with the B- and C-rings and there is also a pi-lone-pair interaction between protein residue Pro285 and the C-ring. Hydrogen bond interaction is predicted between the carbonyl oxygen of the methyl acetate 
group with Glu197 and this oxygen atom is also involved in weak van der Waals interaction with Ser79. The only other weak interaction involving carbon hydrogen bond interaction exists between Gly116 and one of the acetoxy groups. Although the inhibitory effects of $21\left(\mathrm{IC}_{50}=7.24 \mu \mathrm{M}\right)$ and $2 \mathrm{~g}$ $\left(\mathrm{IC}_{50}=7.15 \mu \mathrm{M}\right)$ are comparable, the latter is slightly more active presumably because of halogen bond interaction between $\mathrm{Cl}$ and Trp82. Compound $2 \mathrm{p}$ (Figure $4 \mathrm{~d}$ ), on the other hand, has been found to be the most inhibiting against BChE activity among the title compounds. Its C-ring is involved in pi-anion interaction with Asp70 while the glycoside moiety is involved in weak carbon hydrogen bond and van der Waals interactions with several protein residues. Several hydrophobic (alkyl, pi-alkyl and pi-pi stacking) interactions are predicted between the lipophilic 2-(4-methoxyphenyl) group of compound 2p with the protein residues Trp82, Trp430, Ala328, Met437, and Tyr440 including His438. No hydrogen bond interactions have been predicted between this compound and any of the protein residues. The predicted interaction of these compounds with His438 in the catalytic active site probably accounts for their significant inhibitory effect against BChE activity. These compounds might also bind additional alternative sites on the enzyme consistent with their non-competitive inhibition mode. Binding at alternative sites would alter the enzyme's conformation and hence its catalytic activity.



(a)



(c)



(b)

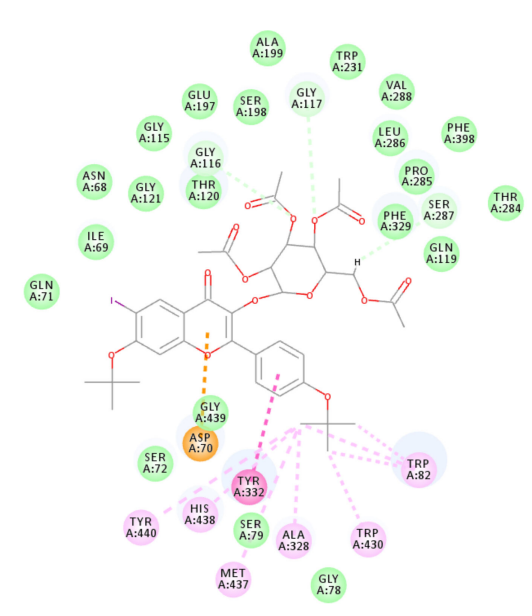

(d)

Figure 4. Docking poses of compounds $2 \mathrm{e}(\mathbf{a}), 2 \mathrm{~g}(\mathrm{~b}), \mathbf{2 l}(\mathrm{c})$, and $2 \mathrm{p}$ (d) into BChE. Bright green represents conventional hydrogen bonds; light green: van der Waals interactions; very light green: carbon hydrogen bonds; orange: pi-anion interaction; light blue: halogen bonds; dark pink: pi-pi interactions; and light pink: pi-alkyl and alkyl interactions. 
Substrates 11 and $1 p$ were previously predicted to form hydrogen bonds with His438 and Ser198 of the catalytic triad of BChE [22] consisting of serine (Ser198), histidine (His438) and glutamate (Glu325) interconnected by hydrogen bonds [32]. The predicted interaction of the glycoside derivatives $\mathbf{2 l}$ and $2 \mathbf{p}$ only with His 438 would probably indicate that these compounds bind $\mathrm{BChE}$, but do not compete with the substrate. This would allow the substrate to bind to the active site and probably account for the non-competitive mode of action confirmed by the kinetic studies above.

\subsubsection{Molecular Docking Studies of Compounds 21 and $\mathbf{2 p}$ into $\beta$-Secretase Active Sites}

$\beta$-Secretase has proven to be a difficult target compared to cholinesterase due to its extended active site and inherent flexibility. The catalytic domain of $\beta$-secretase, for example, contains eight pockets consisting of different amino acid residues [33] and different inhibitors can bind to different sites and a few sites simultaneously [34]. Both compounds $\mathbf{2 l}$ (Figure 5a) and $\mathbf{2 p}$ (Figure 5b) were docked into $\beta$-secretase (PDB 3IXJ) and they are predicted to bind better to the S1' pocket (Figure 5), which accommodates large groups. This pocket is close to the active site comprising of the catalytic aspartate dyad, Asp32 and Asp228. The two compounds exhibit several key protein-ligand interactions including hydrogen bond between ester functions of the glucoside moiety with the protein residues Asp80, Gln121, Thr120, Thr279, and Thr280. Molecular docking predicts several hydrogen bond interactions for compound $\mathbf{2 l}$ than $\mathbf{2 p}$, and this correlates with the observed $\mathrm{IC}_{50}$ values. However, the two compounds show no interaction with the catalytic aspartic acids, Asp32 and Asp228. This is consistent with the observed non-competitive mode of inhibition, which indicates that the binding of these compounds affects the proteins structure and the enzyme's ability to catalyze the reaction. The compounds seem not to bind to the active site, instead, they probably alter the conformational dynamics of the protein affecting catalytic activity. Molecular docking helped to explain the observed inhibitory activity, selectivity, and mechanism of cholinesterase inhibition by these compounds. The docking studies of the title compounds into the $\mathrm{ChE}$ and $\beta$-secretase active sites revealed increased interaction of the glycoside moiety with several protein residues.

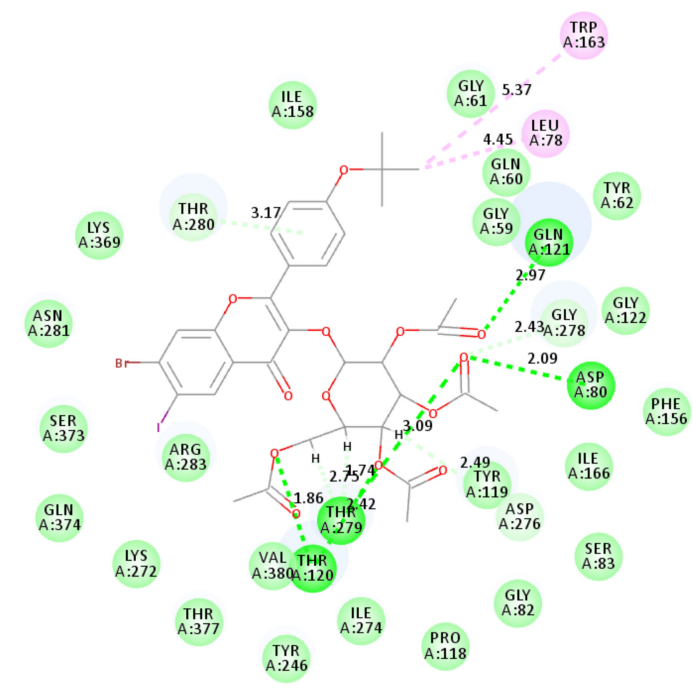

(a)

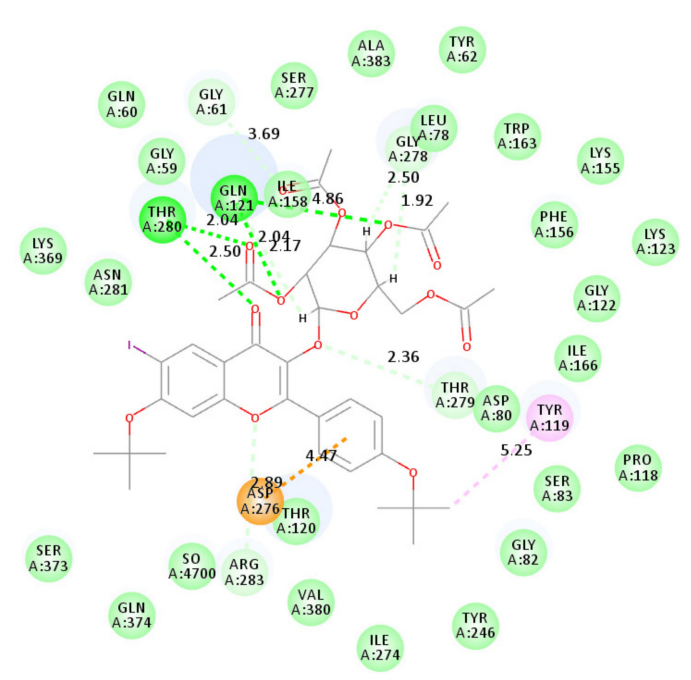

(b)

Figure 5. Docking poses of 21 (a) and $2 p(\mathbf{b})$ into $\beta$-secretase. Bright green represents conventional hydrogen bonds; light green: van der Waals interactions; very light green: carbon hydrogen bonds; orange: pi-anion interaction; dark pink: pi-pi interactions; and light pink: pi-alkyl and alkyl interactions.

Chromones and their flavonoid derivatives are known to play important roles as antioxidants and radical scavengers $[14,35]$. The design of anticholinesterase inhibitors with antioxidant properties, on the other hand, continues to attract considerable attention towards efficient therapy of AD. This 
MTDL design strategy has been found to be more effective in the treatment of Alzheimer's disease than the use of single-targeted drugs [9-11]. Consequently, in the last part of this investigation, we evaluated the most active compounds against $\mathrm{AChE}$ and/or BChE for antioxidant properties.

\subsection{Antioxidant Activity of Compounds $\mathbf{2 g}, \mathbf{2 k}, \mathbf{2 1}, \mathbf{2 n}$, and $\mathbf{2 p}$}

The free-radical scavenging activities of compounds $\mathbf{2 g}$, 2k, 21, 2n, and $\mathbf{2 p}$ were evaluated against the natural antioxidants ascorbic acid and quercetin [36] as reference standards. The results are expressed as $\mathrm{IC}_{50}$ values, i.e., the concentration of each sample required or able to scavenge $50 \%$ of the DPPH (Table 4). Preliminary 2,2-diphenyl-1-picrylhydrazyl (DPPH) radical scavenging results revealed that the most active glycosides against $\mathrm{AChE}$ and/or BChE activity exhibit moderate antioxidant activity $\left(\mathrm{IC}_{50} 11.4-21.6 \mu \mathrm{M}\right)$ when compared to the reference standards, ascorbic acid $\left(\mathrm{IC}_{50}=5.5 \mu \mathrm{M}\right)$ and quercetin $\left(\mathrm{IC}_{50}=3.1 \mu \mathrm{M}\right)$. A combination of the electron-withdrawing 2-(4-chlorophenyl) group and a chlorine or bromine atom at the 7-position of the chromone framework of compounds $2 \mathrm{~g}$ and 2k resulted in significant radical scavenging abilities with $\mathrm{IC}_{50}$ values $13.1 \mu \mathrm{M}$ and $11.4 \mu \mathrm{M}$, respectively. Compounds $\mathbf{2} \mathbf{g}$ and $\mathbf{2 k}$ exhibit increased inhibitory effect against AChE activity and free-radical scavenging ability. A combination of a strongly electron donating 2-(4-methoxyphenyl) group and an electron-withdrawing 7-bromo atom on the framework of $\mathbf{2 1}$, on the other hand, resulted in relatively reduced radical scavenging ability $\left(\mathrm{IC}_{50}=21.6 \mu \mathrm{M}\right)$. On the other hand, a combination of moderately 2-(4-fluorophenyl) and strongly electron delocalizing 7-methoxy groups resulted in significant free-radical scavenging ability for compound $\mathbf{2 n}$. Compounds $\mathbf{2 l}$ and $\mathbf{2} \mathbf{p}$ with potential dual inhibitory activity against $\mathrm{AChE}$ and $\mathrm{BChE}$ exhibited moderate free-radical scavenging ability than the other derivatives. However, the presence of strongly electron donating 7-methoxy group in compound $\mathbf{2 p}$ resulted in higher free-radical scavenging ability than $\mathbf{2 l}$ substituted with a bromine atom at this position. Although compound 2p exhibited relatively reduced activity against BACE-1, it has potential to serve as a dual AChE and BChE inhibitor with antioxidant potential.

Table 4. Scavenging Activity of Compounds 2e, 2g, 2i, 2k, 21, 2n, and 2p.

\begin{tabular}{cc}
\hline Compounds & IC $_{50}(\mu \mathrm{M})$ \\
\hline $\mathbf{2 g}$ & $13.1 \pm 0.01$ \\
$\mathbf{2 k}$ & $11.4 \pm 0.02$ \\
$\mathbf{2}$ & $21.6 \pm 0.03$ \\
$\mathbf{2 n}$ & $14.4 \pm 0.02$ \\
$\mathbf{2 p}$ & $17.9 \pm 0.04$ \\
Ascorbic acid & $5.5 \pm 0.02$ \\
Quercetin & $3.1 \pm 0.01$ \\
\hline
\end{tabular}

Each value represents mean $\pm \mathrm{SD} ; \mathrm{IC}_{50}: 50 \%$ effective concentration.

\section{Materials and Methods}

\subsection{General}

Merck kieselgel 60 (0.063-0.200 mm) (Merck KGaA, Frankfurt, Germany) was used as stationary phase for column chromatography. The melting point (m.p.) values of the prepared compounds were recorded on a Thermocouple digital melting point apparatus and are uncorrected. NMR spectra were recorded using Varian Mercury $300 \mathrm{MHz}$ NMR spectrometer (Varian Inc., Palo Alto, CA, USA) and Agilent $500 \mathrm{MHz}$ NMR spectrometers (Agilent Technologies, Oxford, UK) and the chemical shifts are quoted relative to tetramethylsilane (TMS) peak. IR spectra were recorded by thin-film method using a Bruker VERTEX 70 FT-IR Spectrometer (Bruker Optics, Billerica, MA, USA) fitted with a diamond attenuated total reflectance (ATR) accessory. High-resolution mass spectra were recorded using Waters Synapt G2 Quadrupole Time-of-flight mass spectrometer (Waters Corp., Milford, MA, USA). The synthesis and analytical data of flavonols 1a-1p have been described before [22]. 
3.2. Typical Procedure for the Synthesis of the 7-substituted-6-iodo-2-phenyl-chromen-4-one-3-O-2,3,4,6-Otetraacetyl- $\beta$ - $d$-glucopyranoside Derivatives (2a-2p)

A mixture of $1 \mathrm{a}(0.20 \mathrm{~g}, 0.50 \mathrm{mmol})$, acetobromo- $\alpha$-D-glucose $(0.25 \mathrm{~g}, 0.60 \mathrm{mmol})$ and $\mathrm{K}_{2} \mathrm{CO}_{3}$ $(0.08 \mathrm{~g}, 0.60 \mathrm{mmol})$ in DMF $(20 \mathrm{~mL})$ was stirred at room temperature for $12 \mathrm{~h}$. The reaction was poured onto crush ice. The organic phase was extracted with chloroform and the combined organic layers were dried over anhydrous $\mathrm{MgSO}_{4}$. The solvent was evaporated on a rotary evaporator under reduced pressure. The residue was purified on silica gel column chromatography to afford 2a. Compounds $\mathbf{2 a - 2} \mathbf{p}$ were prepared in this fashion

7-Fluoro-6-iodo-2-phenyl-4H-chromen-4-one-3-O-2,3,4,6-O-tetraacetyl- $\beta$-d-glucopyranoside (2a): White solid (0.25 g, 71\%), $\mathrm{R}_{f}\left(50 \%\right.$ EtOAc-hexane) 0.67, m.p. 219-220 ${ }^{\circ} \mathrm{C} ; v_{\max }$ (ATR) 433, 578, 761, 1032, 1186, 1209, 1421, 1640, 1758, 2614, 3062, $3077 \mathrm{~cm}^{-1}$; ${ }^{1} \mathrm{H}-\mathrm{NMR}\left(300 \mathrm{MHz}, \mathrm{DMSO}-d_{6}\right) 1.85\left(3 \mathrm{H}, \mathrm{s},-\mathrm{C}(\mathrm{O}) \mathrm{CH}_{3}\right), 1.94(3 \mathrm{H}$, $\left.\mathrm{s}-\mathrm{C}(\mathrm{O}) \mathrm{CH}_{3}\right), 1.96\left(3 \mathrm{H}, \mathrm{s},-\mathrm{C}(\mathrm{O}) \mathrm{CH}_{3}\right), 2.03\left(3 \mathrm{H}, \mathrm{s},-\mathrm{C}(\mathrm{O}) \mathrm{CH}_{3}\right), 3.87-3.94(3 \mathrm{H}, \mathrm{m}$, aliphatic $), 4.89-5.00(2 \mathrm{H}$, $\mathrm{m}$, aliphatic), $5.39(1 \mathrm{H}, \mathrm{t}, J=10.0 \mathrm{~Hz}$, aliphatic), $5.75(1 \mathrm{H}, \mathrm{d}, J=7.5 \mathrm{~Hz}$, aliphatic), 7.54-7.57 (3H, m, H-4' and $\left.\mathrm{H}-3^{\prime}, 5^{\prime}\right), 8.04\left(2 \mathrm{H}, \mathrm{d}, J=4.8 \mathrm{~Hz}, \mathrm{H}-2^{\prime}\right.$ and $\left.6^{\prime}\right), 8.14(1 \mathrm{H}, \mathrm{s} \mathrm{H}-8), 8.47(1 \mathrm{H}, \mathrm{s}, \mathrm{H}-5) ;{ }^{13} \mathrm{C}-\mathrm{NMR}(75 \mathrm{MHz}$, DMSO- $\left.d_{6}\right) 20.7,20.8,20.9,61.6,68.3,71.1,71.2,72.2,79.6\left(\mathrm{~d},{ }^{2} J_{\mathrm{CF}}=27.4 \mathrm{~Hz}\right), 105.4\left(\mathrm{~d},{ }^{2} J_{\mathrm{CF}}=28.6 \mathrm{~Hz}\right)$, 120.7, $128.0(2 \times C), 128.9(2 \times C), 130.5(2 \times C), 131.3,135.7\left(d,{ }^{3} J_{C F}=4.6 \mathrm{~Hz}\right), 140.0,146.4,155.7\left(d,{ }^{3} J_{C F}\right.$ $=13.7 \mathrm{~Hz}), 163.6\left(\mathrm{~d},{ }^{1} J_{\mathrm{CF}}=247.2 \mathrm{~Hz}\right), 169.7,170.0,170.1,171.9 ; \mathrm{HRMS}\left(\mathrm{ES}^{+}\right): \mathrm{m} / z[\mathrm{M}+\mathrm{H}]^{+}$calc for $\mathrm{C}_{29} \mathrm{H}_{27} \mathrm{O}_{12} \mathrm{FI}: 713.0531$; found 713.0527.

7-Fluoro-(4-fluorophenyl)-6-iodo-4H-chromen-4-one-3-O-2,3,4,6-O-tetraacetyl- $\beta$-d-glucopyranoside (2b): White solid (0.25 g, 71\%), $R_{f}$ (50\% EtOAc-hexane) 0.66, m.p. 254-255 ${ }^{\circ} \mathrm{C} ; v_{\max }$ (ATR) 452, 542, 771, $1027,1161,1212,1426,1632,1753,2634,3065,3062 \mathrm{~cm}^{-1} ;{ }^{1} \mathrm{H}-\mathrm{NMR}\left(300 \mathrm{MHz}, \mathrm{DMSO}-d_{6}\right) 1.89(3 \mathrm{H}$, $\left.\mathrm{s},-\mathrm{C}(\mathrm{O}) \mathrm{CH}_{3}\right), 1.93\left(3 \mathrm{H}, \mathrm{s},-\mathrm{C}(\mathrm{O}) \mathrm{CH}_{3}\right), 2.01\left(3 \mathrm{H}, \mathrm{s},-\mathrm{C}(\mathrm{O}) \mathrm{CH}_{3}\right), 2.13\left(3 \mathrm{H}, \mathrm{s},-\mathrm{C}(\mathrm{O}) \mathrm{CH}_{3}\right), 3.61(1 \mathrm{H}, \mathrm{d}$, $J=10.5 \mathrm{~Hz}$, aliphatic), 3.59-3.98 (2H, m, aliphatic), $5.07(1 \mathrm{H}, \mathrm{t}, J=9.6 \mathrm{~Hz}$, aliphatic), 5.15-5.32 (2H, m, aliphatic), $5.65\left(1 \mathrm{H}, \mathrm{d}, J=7.5 \mathrm{~Hz}\right.$, aliphatic), $7.01\left(2 \mathrm{H}, \mathrm{d}, J=8.7 \mathrm{~Hz}, \mathrm{H}-3^{\prime}, 5^{\prime}\right), 7.75(1 \mathrm{H}, \mathrm{d}, J=8.1 \mathrm{~Hz}$, H-8), $8.13\left(2 \mathrm{H}, \mathrm{d}, J=9.0 \mathrm{~Hz}, \mathrm{H}-2^{\prime}, 6^{\prime}\right), 8.42(1 \mathrm{H}, \mathrm{d}, J=6.9 \mathrm{~Hz}, \mathrm{H}-5) ; \delta_{\mathrm{C}}\left(75 \mathrm{MHz}, \mathrm{CDCl}_{3}\right) 20.6,20.7,20.8$, 21.0, 68.4, 71.1, 71.3, 73.3, 80.1 (d, $\left.{ }^{2} J_{\mathrm{CF}}=26.3 \mathrm{~Hz}\right), 105.8\left(\mathrm{~d},{ }^{2} J_{\mathrm{CF}}=26.3 \mathrm{~Hz}\right), 114.9\left(\mathrm{~d},{ }^{2} J_{\mathrm{CF}}=24.0 \mathrm{~Hz}\right)$, $116.3\left(\mathrm{~d},{ }^{2} J_{\mathrm{CF}}=21.75 \mathrm{~Hz}\right), 119.0\left(\mathrm{~d},{ }^{4} J_{\mathrm{CF}}=22.8 \mathrm{~Hz}\right), 130.5\left(\mathrm{~d},{ }^{4} J_{\mathrm{CF}}=3.4 \mathrm{~Hz}\right), 131.0\left(\mathrm{~d},{ }^{3} J_{\mathrm{CF}}=8.025 \mathrm{~Hz}\right)$, $140.3\left(\mathrm{~d},{ }^{4} J_{\mathrm{CF}}=4.5 \mathrm{~Hz}\right), 145.4,164.5,164.1,\left(\mathrm{~d},{ }^{1} J_{\mathrm{CF}}=251.9 \mathrm{~Hz}\right), 165.3\left(\mathrm{~d},{ }^{1} J_{\mathrm{CF}}=249.4 \mathrm{~Hz}\right), 169.8,170.0$, 170.1, 171.3; HRMS $\left(\mathrm{ES}^{+}\right): \mathrm{m} / z[\mathrm{M}+\mathrm{H}]^{+}$calc for $\mathrm{C}_{29} \mathrm{H}_{26} \mathrm{O}_{12} \mathrm{~F}_{2} \mathrm{I}$ : 731.0437; found 731.0433 .

7-Fluoro-2-(4-Chlorophenyl)-6-iodo-4H-chromen-4-one-3-O-2,3,4,6-O-tetraacetyl- $\beta$ - $d$-glucopyranoside (2c): Brown solid (0.28 g, 77\%), $\mathrm{R}_{f}\left(50 \%\right.$ EtOAc-hexane) 0.72, m.p. 260-261 ${ }^{\circ} \mathrm{C} ; v_{\max }$ (ATR) 465, 562, 768, $1029,1163,1214,1430,1635,1754,2640,3065,3071 \mathrm{~cm}^{-1},{ }^{1} \mathrm{H}-\mathrm{NMR}\left(300 \mathrm{MHz}, \mathrm{DMSO}-d_{6}\right) 1.80(3 \mathrm{H}, \mathrm{s}$, $\left.-\mathrm{C}(\mathrm{O}) \mathrm{CH}_{3}\right), 1.95\left(3 \mathrm{H}, \mathrm{s}-\mathrm{C}(\mathrm{O}) \mathrm{CH}_{3}\right), 2.00\left(3 \mathrm{H}, \mathrm{s},-\mathrm{C}(\mathrm{O}) \mathrm{CH}_{3}\right), 2.05\left(3 \mathrm{H}, \mathrm{s},-\mathrm{C}(\mathrm{O}) \mathrm{CH}_{3}\right), 3.88-3.97(3 \mathrm{H}, \mathrm{m}$, aliphatic), 4.93-5.06 (2H, m, aliphatic), $5.40(1 \mathrm{H}, \mathrm{t}, J=9.9 \mathrm{~Hz}$, aliphatic), $5.75(1 \mathrm{H}, \mathrm{d}, J=8.1 \mathrm{~Hz}$, aliphatic), $7.07\left(2 \mathrm{H}, \mathrm{d}, J=9.3 \mathrm{~Hz}, \mathrm{H}-3^{\prime}, 5^{\prime}\right), 7.77(1 \mathrm{H}, \mathrm{d}, J=8.4 \mathrm{~Hz}, \mathrm{H}-8), 8.07\left(2 \mathrm{H}, \mathrm{d}, J=9.3 \mathrm{~Hz}, \mathrm{H}-2^{\prime}, 6^{\prime}\right), 8.40(1 \mathrm{H}$, $\mathrm{d}, J=6.9 \mathrm{~Hz}, \mathrm{H}-5) ;{ }^{13} \mathrm{C}-\mathrm{NMR}\left(75 \mathrm{MHz}, \mathrm{DMSO}-d_{6}\right)$ 20.6, 20.7, 20.8, 21.0. 61.6, 68.3, 71.0, 71.8, 72.2, 80.2 $\left(\mathrm{d},{ }^{2} J_{\mathrm{CF}}=28.6 \mathrm{~Hz}\right), 98.7,106.2\left(\mathrm{~d},{ }^{2} J_{\mathrm{CF}}=28.7 \mathrm{~Hz}\right), 114.2,122.3\left(\mathrm{~d},{ }^{3} J_{C F}=12.6 \mathrm{~Hz}\right), 122.5,131.3,135.6$, $136.1\left(\mathrm{~d},{ }^{4} J_{\mathrm{CF}}=4.75 \mathrm{~Hz}\right), 155.9\left(\mathrm{~d},{ }^{3} J_{\mathrm{CF}}=13.4 \mathrm{~Hz}\right), 157.4,161.9,163.9,\left(\mathrm{~d},{ }^{1} J_{\mathrm{CF}}=248.5 \mathrm{~Hz}\right), 169.7,169.8$, 170.0, 170.1, 171.4; HRMS $\left(\mathrm{ES}^{+}\right): \mathrm{m} / z[\mathrm{M}+\mathrm{H}]^{+}$calc for $\mathrm{C}_{29} \mathrm{H}_{26} \mathrm{O}_{12} \mathrm{~F}^{35} \mathrm{ClI}$ : 747.0142; found 747.0137.

7-Fluoro-6-iodo-2-(4-methoxyphenyl)-4H-chromen-4-one-3-O-2,3,4,6-O-tetraacetyl- $\beta$-d-glucopyranoside (2d): White solid (0.28 g, 80\%), $\mathrm{R}_{f}\left(50 \%\right.$ EtOAc-hexane) 0.63, m.p. 247-248 ${ }^{\circ} \mathrm{C} ; v_{\max }$ (ATR) 472, 573, 760, 1024, $\left.1161,1204,1423,1638,1748,2656,3079,3077 \mathrm{~cm}^{-1} ; \delta_{\mathrm{H}}\left(500 \mathrm{MHz}, \mathrm{DMSO}-d_{6}\right) 1.80(3 \mathrm{H}, \mathrm{s},-\mathrm{C}(\mathrm{O}) \mathrm{CH})\right)$ $1.96\left(3 \mathrm{H}, \mathrm{s}-\mathrm{C}(\mathrm{O}) \mathrm{CH}_{3}\right), 2.00\left(3 \mathrm{H}, \mathrm{s},-\mathrm{C}(\mathrm{O}) \mathrm{CH}_{3}\right), 2.05\left(3 \mathrm{H}, \mathrm{s},-\mathrm{C}(\mathrm{O}) \mathrm{CH}_{3}\right), 3.85\left(3 \mathrm{H}, \mathrm{s},-\mathrm{C}(\mathrm{O}) \mathrm{CH}_{3}\right), 3.86-3.96$ (3H, m, aliphatic), 4.91-5.05 (2H, m, aliphatic), $5.41(1 \mathrm{H}, \mathrm{t}, J=10.0 \mathrm{~Hz}$, aliphatic), $5.76(1 \mathrm{H}, \mathrm{d}, J=8.0$ $\mathrm{Hz}$, aliphatic), $7.09\left(2 \mathrm{H}, \mathrm{d}, J=9.0 \mathrm{~Hz}, \mathrm{H}-3^{\prime}, 5^{\prime}\right), 7.80(1 \mathrm{H}, \mathrm{d}, J=8.5 \mathrm{~Hz}, \mathrm{H}-8), 8.08(2 \mathrm{H}, \mathrm{d}, J=8.5 \mathrm{~Hz}$, H-2' $\left.6^{\prime}\right), 8.39(1 \mathrm{H}, \mathrm{d}, J=7.0 \mathrm{~Hz}, \mathrm{H}-5) ; \delta_{\mathrm{C}}{ }^{13} \mathrm{C}-\mathrm{NMR}\left(125 \mathrm{MHz}, \mathrm{DMSO}-d_{6}\right)$ 20.6, 20.7, 20.8, 20.9, 55.9, $61.6,68.4,71.1,71.8,72.2,80.2\left(\mathrm{~d},{ }^{2} J_{\mathrm{CF}}=28.5 \mathrm{~Hz}\right), 98.7,106.1\left(\mathrm{~d},{ }^{2} J_{C F}=29.4 \mathrm{~Hz}\right), 114.1,122.4\left(\mathrm{~d},{ }^{3} J_{\mathrm{CF}}\right.$ $=16.1 \mathrm{~Hz}), 122.5,131.2,135.6,136.0\left(\mathrm{~d},{ }^{4} J_{\mathrm{CF}}=4.6 \mathrm{~Hz}\right), 156.0\left(\mathrm{~d},{ }^{3} J_{\mathrm{CF}}=13.7 \mathrm{~Hz}\right), 157.5,162.0,163.8$, 
$\left(\mathrm{d},{ }^{1} J_{\mathrm{CF}}=248.3 \mathrm{~Hz}\right), 169.7,169.8,169.9,170.1,171.3$; HRMS $\left(\mathrm{ES}^{+}\right): \mathrm{m} / \mathrm{z}[\mathrm{M}+\mathrm{H}]^{+}$calc for $\mathrm{C}_{30} \mathrm{H}_{29} \mathrm{O}_{13} \mathrm{FI}$ : 743.0637; found 743.0637.

7-Chloro-6-iodo-2-phenyl-4H-chromen-4-one-3-O-2,3,4,6-O-tetraacetyl- $\beta$-d-glucopyranoside (2e): White solid (0.26 g, 73\%), $\mathrm{R}_{f}\left(50 \%\right.$ EtOAc-hexane) 0.67, m.p. $212-213^{\circ} \mathrm{C} ; v_{\max }$ (ATR) 438, 589, 772, 1036, 1194, 1214, 1425, 1645, 1750, 2611, 3064, $3078 \mathrm{~cm}^{-1} ;{ }^{1} \mathrm{H}-\mathrm{NMR}$ (300 MHz, DMSO-d $\left.\mathrm{d}_{6}\right) 1.89\left(3 \mathrm{H}, \mathrm{s},-\mathrm{C}(\mathrm{O}) \mathrm{CH}_{3}\right), 2.02$ $\left(3 \mathrm{H}, \mathrm{s}-\mathrm{C}(\mathrm{O}) \mathrm{CH}_{3}\right), 2.10\left(3 \mathrm{H}, \mathrm{s},-\mathrm{C}(\mathrm{O}) \mathrm{CH}_{3}\right), 2.10\left(3 \mathrm{H}, \mathrm{s},-\mathrm{C}(\mathrm{O}) \mathrm{CH}_{3}\right), 3.44-3.51(2 \mathrm{H}, \mathrm{m}$, aliphatic), 3.63 $(1 \mathrm{H}, \mathrm{d}, J=9.3 \mathrm{~Hz}$, aliphatic), $5.07(1 \mathrm{H}, \mathrm{t}, J=9.3 \mathrm{~Hz}$, aliphatic), 5.15-5.31 $(2 \mathrm{H}, \mathrm{m}$, aliphatic $), 5.67(1 \mathrm{H}, \mathrm{d}$, $J=7.8 \mathrm{~Hz}$, aliphatic), $7.50\left(3 \mathrm{H}, \mathrm{m}, \mathrm{H}-4^{\prime}\right.$ and $\left.\mathrm{H}-3^{\prime}, 5^{\prime}\right), 7.69(1 \mathrm{H}, \mathrm{s} \mathrm{H}-8), 8.00\left(2 \mathrm{H}, \mathrm{d}, J=4.8 \mathrm{~Hz}, \mathrm{H}-2^{\prime}\right.$ and $\left.6^{\prime}\right), 8.68(1 \mathrm{H}, \mathrm{s}, \mathrm{H}-5) ;{ }^{13} \mathrm{C}-\mathrm{NMR}\left(75 \mathrm{MHz}\right.$, DMSO- $\left.d_{6}\right)$ 15.3, 20.5, 20.6, 20.8, 61.3, 65.9, 68.1, 71.5, 71.7, 72.6, 93.6, 98.8, 118.8, 123.8, 128.3, 129.1, 130.0, 131.2, 137.2, 143.7, 155.0, 157.7, 169.5, 169.8, 170.1, 170.3, 172.0; HRMS (ES ${ }^{+}$): $m / z[\mathrm{M}+\mathrm{H}]^{+}$calc for $\mathrm{C}_{29} \mathrm{H}_{27} \mathrm{O}_{12}{ }^{35} \mathrm{ClI}$ : 729.0236; found 729.0234.

7-Chloro-2-(4-fluorophenyl)-6-iodo-4H-chromen-4-one-3-O-2,3,4,6-O-tetraacetyl- $\beta$-d-glucopyranoside (2f): White solid (0.26 g, 66\%), $\mathrm{R}_{f}\left(50 \%\right.$ EtOAc-hexane) 0.68, m.p. $198-199{ }^{\circ} \mathrm{C} ; v_{\max }$ (ATR) 469, 566, 777, 1039, 1154, 1213, 1430, 1643, 1754, 2642, 3071, $3076 \mathrm{~cm}^{-1}$; ${ }^{1} \mathrm{H}-\mathrm{NMR}(300 \mathrm{MHz}$, DMSO-d 6$) 1.90(3 \mathrm{H}$, $\left.\mathrm{s},-\mathrm{C}(\mathrm{O}) \mathrm{CH}_{3}\right), 2.00\left(3 \mathrm{H}, \mathrm{s}-\mathrm{C}(\mathrm{O}) \mathrm{CH}_{3}\right), 2.01\left(3 \mathrm{H}, \mathrm{s},-\mathrm{C}(\mathrm{O}) \mathrm{CH}_{3}\right), 2.17\left(3 \mathrm{H}, \mathrm{s},-\mathrm{C}(\mathrm{O}) \mathrm{CH}_{3}\right), 3.54-3.66(1 \mathrm{H}, \mathrm{m}$, aliphatic), 3.83-4.12 $(2 \mathrm{H}, \mathrm{m}), 5.06(1 \mathrm{H}, \mathrm{t}, J=9.5 \mathrm{~Hz}$, aliphatic), 5.14-5.31 $(2 \mathrm{H}, \mathrm{m}$, aliphatic), $5.65(1 \mathrm{H}, \mathrm{d}$, $J=7.5 \mathrm{~Hz}$, aliphatic), $7.84\left(2 \mathrm{H}, \mathrm{dd}, J_{\mathrm{HH}}=8.7\right.$ and $\left.J_{\mathrm{HF}}=9.7 \mathrm{~Hz}, \mathrm{H}-3^{\prime}, 5^{\prime}\right), 8.51\left(2 \mathrm{H}, 2 \mathrm{H}, \mathrm{dd}, J_{\mathrm{HH}}=8.7 \mathrm{~Hz}\right.$ and $\left.J_{\mathrm{HF}}=5.4 \mathrm{~Hz}, \mathrm{H}-2^{\prime}, 6^{\prime}\right), 8.57(1 \mathrm{H}, \mathrm{s} \mathrm{H}-8), 8.78(1 \mathrm{H}, \mathrm{s}, \mathrm{H}-5) ;{ }^{13} \mathrm{C}-\mathrm{NMR}\left(75 \mathrm{MHz}, \mathrm{DMSO}-d_{6}\right)$ 20.4, 20.5, 20.6, 20.7, 20.8, 61.4, 68.3, 71.6, 71.7, 72.7, 98.8, 104.7, 105.1, $116.3\left(\mathrm{~d},{ }^{2} J_{\mathrm{CF}}=21.8 \mathrm{~Hz}\right), 118.9,119.7,120.7$, $130.4\left(\mathrm{~d},{ }^{4} J_{\mathrm{CF}}=3.4 \mathrm{~Hz}\right), 130.9\left(\mathrm{~d},{ }^{3} J_{\mathrm{CF}}=8.0 \mathrm{~Hz}\right), 156.0,157.8,164.1\left(\mathrm{~d},{ }^{1} J_{\mathrm{CF}}=251.9 \mathrm{~Hz}\right), 169.5,169.9$, 170.0, 170.3, 171.7; HRMS (ES $\left.{ }^{+}\right): m / z[\mathrm{M}+\mathrm{H}]^{+}$calc for $\mathrm{C}_{29} \mathrm{H}_{26} \mathrm{O}_{12} \mathrm{~F}^{35} \mathrm{ClI}$ : 747.0142; found 747.0141.

7-Chloro-2-(4-chlorophenyl)-6-iodo-4H-chromen-4-one-3-O-2,3,4,6-O-tetraacetyl- $\beta$-d-glucopyranoside (2g): White solid $(0.28 \mathrm{~g}, 69 \%), \mathrm{R}_{f}\left(50 \%\right.$ EtOAc-hexane) 0.63, m.p. $252-257^{\circ} \mathrm{C}$; $v_{\max }$ (ATR) 482, 556, 761, 1023, 1160, 1208, 1422, 1639, 1747, 2651, 3063, $3075 \mathrm{~cm}^{-1} ;{ }^{1} \mathrm{H}-\mathrm{NMR}(300 \mathrm{MHz}$, DMSO-d 6 ) 1.90 (3H, s, $\left.-\mathrm{C}(\mathrm{O}) \mathrm{CH}_{3}\right), 1.99\left(3 \mathrm{H}, \mathrm{s}-\mathrm{C}(\mathrm{O}) \mathrm{CH}_{3}\right), 2.01\left(3 \mathrm{H}, \mathrm{s},-\mathrm{C}(\mathrm{O}) \mathrm{CH}_{3}\right), 2.13,\left(3 \mathrm{H}, \mathrm{s},-\mathrm{C}(\mathrm{O}) \mathrm{CH}_{3}\right), 3.57-3.63(1 \mathrm{H}, \mathrm{m}$, aliphatic), 3.93-3.98 (2H, m, aliphatic), $5.07(1 \mathrm{H}, \mathrm{t}, J=9.6 \mathrm{~Hz}$, aliphatic), 5.15-5.32 (2H, $\mathrm{m}$, aliphatic), 5.57 $\left(1 \mathrm{H}, \mathrm{d}, J=7.5 \mathrm{~Hz}\right.$, aliphatic), $7.47\left(2 \mathrm{H}, \mathrm{d}, J=8.7 \mathrm{~Hz}, \mathrm{H}-3^{\prime}, 5^{\prime}\right), 7.69(1 \mathrm{H}, \mathrm{s}, \mathrm{H}-8), 8.00(2 \mathrm{H}, \mathrm{d}, J=9.0 \mathrm{~Hz}$, H-2' $\left.{ }^{\prime} 6^{\prime}\right), 8.67(1 \mathrm{H}, \mathrm{s}, \mathrm{H}-5) ;{ }^{13} \mathrm{C}-\mathrm{NMR}$ (75 MHz, DMSO- $\left.d_{6}\right)$ 20.5, 20.6, 20.7, 20.8, 61.1, 68.0, 71.4, 71.8, 72.5, $93.8,98.9,118.8,123.8,128.4,128.6,130.4,136.5,137.2,137.5,143.9,154.8,156.6,169.4,169.9,170.0,170.3$, 171.9; HRMS $\left(\mathrm{ES}^{+}\right): m / z[\mathrm{M}+\mathrm{H}]^{+}$calc for $\mathrm{C}_{29} \mathrm{H}_{26} \mathrm{O}_{12}{ }^{35} \mathrm{Cl}_{2} \mathrm{I}$ : 762.9846; found 762.98426.

7-Chloro-6-iodo-2-(4-methoxyphenyl)-4H-chromen-4-one-3-O-2,3,4,6-O-tetraacetyl- $\beta$-d-glucopyranoside (2h): White solid (0.28 g, 78\%), $\mathrm{R}_{f}\left(50 \%\right.$ EtOAc-hexane) 0.71, m.p. 161-162 ${ }^{\circ} \mathrm{C} ; v_{\max }$ (ATR) 471, 587, 760, 1027, 1161, 1203, 1418, 1632, 1750, 2654, 3070, $3071 \mathrm{~cm}^{-1},{ }^{1} \mathrm{H}-\mathrm{NMR}\left(300 \mathrm{MHz}, \mathrm{DMSO}-d_{6}\right) 1.88(3 \mathrm{H}, \mathrm{s}$, $\left.-\mathrm{C}(\mathrm{O}) \mathrm{CH}_{3}\right), 2.02\left(3 \mathrm{H}, \mathrm{s}-\mathrm{C}(\mathrm{O}) \mathrm{CH}_{3}\right), 2.04\left(3 \mathrm{H}, \mathrm{s},-\mathrm{C}(\mathrm{O}) \mathrm{CH}_{3}\right), 2.12\left(3 \mathrm{H}, \mathrm{s},-\mathrm{C}(\mathrm{O}) \mathrm{CH}_{3}\right), 3.62-3.66(1 \mathrm{H}, \mathrm{m}$, aliphatic), $3.90\left(3 \mathrm{H}, \mathrm{s},-\mathrm{OCH}_{3}\right), 3.90-3.98(2 \mathrm{H}, \mathrm{m}$, aliphatic), $5.00(1 \mathrm{H}, \mathrm{t}, J=9.6 \mathrm{~Hz}$, aliphatic), 5.18-5.32 $\left(2 \mathrm{H}, \mathrm{m}\right.$, aliphatic), $5.67\left(1 \mathrm{H}, \mathrm{d}, J=7.5 \mathrm{~Hz}\right.$, aliphatic), $7.00\left(2 \mathrm{H}, \mathrm{d}, J=9.0 \mathrm{~Hz}, \mathrm{H}-3^{\prime}, 5^{\prime}\right), 7.68(1 \mathrm{H}, \mathrm{s}, \mathrm{H}-8)$, $8.01\left(2 \mathrm{H}, \mathrm{d}, J=9.6 \mathrm{~Hz}, \mathrm{H}-2^{\prime}, 6^{\prime}\right), 8.65$ (1H, s, H-5); ${ }^{13} \mathrm{C}-\mathrm{NMR}$ (75 MHz, DMSO- $\left.d_{6}\right)$ 20.4, 20.5, 20.6, 20.7, 20.8, 55.4, 61.4, 68.3, 71.6, 71.7, 72.7, 93.3, 98.9, 113.7, 118.7, 122.2, 123.9, 131.0, 135.8, 137.1, 143.4, 154.8, 157.7, 161.9, 169.5, 170.0, 170.3, 171.7; HRMS $\left(\mathrm{ES}^{+}\right): \mathrm{m} / z[\mathrm{M}+\mathrm{H}]^{+}$calc for $\mathrm{C}_{30} \mathrm{H}_{29} \mathrm{O}_{13}{ }^{35} \mathrm{ClI}$ : 759.0341; found 759.0338 .

7-Bromo-6-iodo-2-phenyl-4H-chromen-4-one-3-O-2,3,4,6-O-tetraacetyl- $\beta$-d-glucopyranoside (2i): Brown solid (0.28 g, $80 \%$ ), $\mathrm{R}_{f}\left(50 \%\right.$ EtOAc-hexane) 0.65, m.p.278-279 ${ }^{\circ} \mathrm{C} ; v_{\max }$ (ATR) 468, 601, 691, 838, 917, 1033, 1191, 1219, 1422, 1591, 1643, $1738 \mathrm{~cm}^{-1} ;{ }^{1} \mathrm{H}-\mathrm{NMR}\left(500 \mathrm{MHz}, \mathrm{DMSO}-d_{6}\right) 1.81\left(3 \mathrm{H}, \mathrm{s},-\mathrm{C}(\mathrm{O}) \mathrm{CH}_{3}\right), 1.94$ $\left(3 \mathrm{H}, \mathrm{s}-\mathrm{C}(\mathrm{O}) \mathrm{CH}_{3}\right), 1.95\left(3 \mathrm{H}, \mathrm{s},-\mathrm{C}(\mathrm{O}) \mathrm{CH}_{3}\right), 2.03\left(3 \mathrm{H}, \mathrm{s},-\mathrm{C}(\mathrm{O}) \mathrm{CH}_{3}\right), 3.87-4.0(3 \mathrm{H}, \mathrm{m}$, aliphatic), 4.89-5.00 (2H, m, aliphatic), $5.40(1 \mathrm{H}, \mathrm{t}, J=9.0 \mathrm{~Hz}$, aliphatic), 5.75-5.31 (2H, m, aliphatic), 7.50-7.56 (3H, m, H-4' and $\left.\mathrm{H}-3^{\prime}, 5^{\prime}\right), 8.01\left(2 \mathrm{H}, \mathrm{d}, J=7.5 \mathrm{~Hz}, \mathrm{H}-2^{\prime}, 6^{\prime}\right), 8.25(1 \mathrm{H}, \mathrm{s} \mathrm{H}-8), 8.43(1 \mathrm{H}, \mathrm{s}, \mathrm{H}-5) ;{ }^{13} \mathrm{C}-\mathrm{NMR}(125 \mathrm{MHz}$, DMSO- $d_{6}$ ) 20.7, 20.8, 20.9, 61.6, 68.3, 71.1, 71.8, 72.2, 98.5, 98.6, 123.3, 124.3, 128.7, 129.0, 129.5, 130.3, 


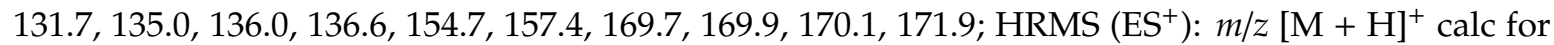
$\mathrm{C}_{29} \mathrm{H}_{27} \mathrm{O}_{12}{ }^{79} \mathrm{BrI}$ : 772.9731; found 772.9725.

7-Bromo-2-(4-fluorophenyl)-6-iodo-4H-chromen-4-one-3-O-2,3,4,6-O-tetraacetyl- $\beta$ - $d$-glucopyranoside (2j): Brown solid (0.23 g, 72\%), $\mathrm{R}_{f}\left(50 \%\right.$ EtOAc-hexane) 0.69, m.p. $248-249{ }^{\circ} \mathrm{C} ; v_{\max }$ (ATR) 475, 566, 770, 1021, 1160, 1218, 1433, 1631, 1758, 2644, 3060, $3075 \mathrm{~cm}^{-1} ;{ }^{1} \mathrm{H}-\mathrm{NMR}\left(300 \mathrm{MHz}, \mathrm{DMSO}-d_{6}\right) 1.17$ (3H, s, $\left.-\mathrm{C}(\mathrm{O}) \mathrm{CH}_{3}\right), 2.00\left(3 \mathrm{H}, \mathrm{s}-\mathrm{C}(\mathrm{O}) \mathrm{CH}_{3}\right), 2.01\left(3 \mathrm{H}, \mathrm{s},-\mathrm{C}(\mathrm{O}) \mathrm{CH}_{3}\right), 2.10\left(3 \mathrm{H}, \mathrm{s},-\mathrm{C}(\mathrm{O}) \mathrm{CH}_{3}\right), 3.64(1 \mathrm{H}, \mathrm{d}, J=9.3 \mathrm{~Hz}$, aliphatic), $3.95(2 \mathrm{H}, \mathrm{s}$, aliphatic), $5.07(1 \mathrm{H}, \mathrm{t}, J=9.3 \mathrm{~Hz}$, aliphatic), 5.15-5.31 $(2 \mathrm{H}, \mathrm{m}$, aliphatic), $5.67(1 \mathrm{H}$, $\mathrm{d}, J=7.8 \mathrm{~Hz}$, aliphatic), $7.56\left(2 \mathrm{H}, \mathrm{dd}, J_{\mathrm{HH}}=8.7\right.$ and $\left.J_{\mathrm{HF}}=9.7 \mathrm{~Hz}, \mathrm{H}-3^{\prime}, 5^{\prime}\right), 8.10(1 \mathrm{H}, \mathrm{s}, \mathrm{H}-8), 8.29(2 \mathrm{H}, \mathrm{dd}$, $J_{\mathrm{HH}}=8.7 \mathrm{~Hz}$ and $\left.J_{\mathrm{HF}}=5.4 \mathrm{~Hz}, \mathrm{H}-2^{\prime}, 6^{\prime}\right), 8.50(1 \mathrm{H}, \mathrm{s}, \mathrm{H}-5) ;{ }^{13} \mathrm{C}-\mathrm{NMR}\left(75 \mathrm{MHz}, \mathrm{DMSO}-d_{6}\right) 20.4,20.5,20.6$, 20.7, 20.8, 61.4, 68.2, 71.6, 71.7, 72.6, 77.8, 98.8, 104.7, 105.1, $116.2\left(\mathrm{~d},{ }^{2} J_{\mathrm{CF}}=21.8 \mathrm{~Hz}\right), 118.8,119.6,120.5$, $130.4\left(\mathrm{~d},{ }^{4} J_{\mathrm{CF}}=3.5 \mathrm{~Hz}\right), 131.0\left(\mathrm{~d},{ }^{3} J_{\mathrm{CF}}=8.0 \mathrm{~Hz}\right), 155.7,155.9,157.8,164.1\left(\mathrm{~d},{ }^{1} J_{\mathrm{CF}}=251.9 \mathrm{~Hz}\right), 169.9$, 170.0, 170.3, 171.7; HRMS (ES $\left.{ }^{+}\right): m / z[\mathrm{M}+\mathrm{H}]^{+}$calc for $\mathrm{C}_{29} \mathrm{H}_{26} \mathrm{O}_{12} \mathrm{~F}^{79} \mathrm{BrI}$ : 790.9636; found 790.9631.

7-Bromo-2-(4-chlorophenyl)-6-iodo-4H-chromen-4-one-3-O-2,3,4,6-O-tetraacetyl- $\beta$-d-glucopyranoside (2k): Brown solid (0.25 g, 74\%), $\mathrm{R}_{f}\left(50 \%\right.$ EtOAc-hexane) 0.70, m.p. $298-299{ }^{\circ} \mathrm{C} ; v_{\max }$ (ATR) 478, 570, 769, $1027,1162,1208,1430,1635,1760,2654,3061,3072 \mathrm{~cm}^{-1} ;{ }^{1} \mathrm{H}-\mathrm{NMR}\left(500 \mathrm{MHz}, \mathrm{DMSO}-d_{6}\right) 1.82(3 \mathrm{H}, \mathrm{s}$, $\left.-\mathrm{C}(\mathrm{O}) \mathrm{CH}_{3}\right), 1.94\left(6 \mathrm{H}, \mathrm{s}, 2 \mathrm{x}-\mathrm{C}(\mathrm{O}) \mathrm{CH}_{3}\right), 2.04\left(3 \mathrm{H}, \mathrm{s},-\mathrm{C}(\mathrm{O}) \mathrm{CH}_{3}\right), 3.82-3.97(3 \mathrm{H}, \mathrm{m}$, aliphatic), 4.90-5.03 $(1 \mathrm{H}, \mathrm{m}$, aliphatic), $5.38(1 \mathrm{H}, \mathrm{t}, J=10.0 \mathrm{~Hz}$, aliphatic), $5.68(1 \mathrm{H}, \mathrm{d}, J=8.0 \mathrm{~Hz}$, aliphatic), $7.61(2 \mathrm{H}, \mathrm{d}$, $\left.J=9.0 \mathrm{~Hz}, \mathrm{H}-3^{\prime}, 5^{\prime}\right), 8.10\left(2 \mathrm{H}, \mathrm{d}, J=8.5 \mathrm{~Hz}, \mathrm{H}-2^{\prime}, 6^{\prime}\right), 8.12(1 \mathrm{H}, \mathrm{s} \mathrm{H}-8), 8.44(1 \mathrm{H}, \mathrm{s}, \mathrm{H}-5) ;{ }^{13} \mathrm{C}-\mathrm{NMR}(125$ MHz, DMSO- $d_{6}$ ) 20.6, 20.7, 20.8, 21.0, 61.5, 68.2, 71.1, 71.7, 72.1, 95.6, 99.0, 120.0, 124.0, 128.8, 129.1, 131.3, 136.3, 136.5, 136.7, 143.1, 155.0, 156.4, 169.7, 169.8, 169.9, 170.1, 171.7; HRMS (ES $\left.{ }^{+}\right): m / z ~[M+]^{+}$ calc for $\mathrm{C}_{29} \mathrm{H}_{26} \mathrm{O}_{12}{ }^{35} \mathrm{Cl}^{79} \mathrm{BrI}$ : 806.9341; found 806.9338.

7-Bromo-6-iodo-2-(4-methoxyphenyl)-4H-chromen-4-one-3-O-2,3,4,6-O-tetraacetyl- $\beta$ - $d$-glucopyranoside (21): Brown solid (0.24 g, 74\%), $\mathrm{R}_{f}$ (50\% EtOAc-hexane) 0.64, m.p. 266-267 ${ }^{\circ} \mathrm{C} ; v_{\max }$ (ATR) 508, 525, 589, 655, 838, 1027, 1182, 1216, 1426, 1890, 1641, 1737, 2360, 2921, $3078 \mathrm{~cm}^{-1} ;{ }^{1} \mathrm{H}-\mathrm{NMR}\left(300 \mathrm{MHz}\right.$, DMSO-d $\left.d_{6}\right) 1.88$ $\left(3 \mathrm{H}, \mathrm{s},-\mathrm{C}(\mathrm{O}) \mathrm{CH}_{3}\right), 2.00\left(3 \mathrm{H}, \mathrm{s}-\mathrm{C}(\mathrm{O}) \mathrm{CH}_{3}\right), 2.02\left(3 \mathrm{H}, \mathrm{s},-\mathrm{C}(\mathrm{O}) \mathrm{CH}_{3}\right), 2.17\left(3 \mathrm{H}, \mathrm{s},-\mathrm{C}(\mathrm{O}) \mathrm{CH}_{3}\right), 3.61-3.66$ $\left(1 \mathrm{H}, \mathrm{m}\right.$, aliphatic), $3.90\left(3 \mathrm{H}, \mathrm{s},-\mathrm{OCH}_{3}\right), 3.92-3.98(2 \mathrm{H}, \mathrm{m}$, aliphatic $), 5.08(1 \mathrm{H}, \mathrm{t}, J=9.3 \mathrm{~Hz}$, aliphatic), $5.18-5.23\left(2 \mathrm{H}, \mathrm{m}\right.$, aliphatic), $5.70\left(1 \mathrm{H}, \mathrm{d}, J=7.5 \mathrm{~Hz}\right.$, aliphatic), $7.00\left(2 \mathrm{H}, \mathrm{d}, J=9.0 \mathrm{~Hz}, \mathrm{H}-3^{\prime}, 5^{\prime}\right), 7.87(1 \mathrm{H}$, s, H-8), $8.05\left(2 \mathrm{H}, \mathrm{d}, J=8.7 \mathrm{~Hz}, \mathrm{H}-2^{\prime}, 6^{\prime}\right), 8.64(1 \mathrm{H}, \mathrm{s}, \mathrm{H}-5) ;{ }^{13} \mathrm{C}-\mathrm{NMR}\left(75 \mathrm{MHz}\right.$, DMSO- $\left.d_{6}\right)$ 20.5, 20.6, 20.8, 55.4, 61.4, 68.2, 71.6, 71.7, 72.3, 96.3, 98.8, 113.7, 122.2, 124.3, 127.8, 131.0, 134.8, 136.9, 154.5, 157.6, 161.9, 169.5, 169.9, 170.0, 170.3, 171.9; HRMS $\left(\mathrm{ES}^{+}\right): \mathrm{m} / z[\mathrm{M}+\mathrm{H}]^{+}$calc for $\mathrm{C}_{30} \mathrm{H}_{29} \mathrm{O}_{13}{ }^{79} \mathrm{BrI}$ : 802.9836; found 802.9832 .

6-Iodo-7-methoxy-2-phenyl-4H-chromen-4-one-3-O-2,3,4,6-O-tetraacetyl- $\beta$-d-glucopyranoside (2m): Brown solid (0.29 g, $81 \%$ ), $\mathrm{R}_{f}$ (50\% EtOAc-hexane) 0.62, m.p. $169-170^{\circ} \mathrm{C} ; v_{\max }$ (ATR) 510, 528, 579, 653, 840, $1024,1172,1213,1422,1590,1644,1731,2360,2918,3070 \mathrm{~cm}^{-1} ;{ }^{1} \mathrm{H}\left(300 \mathrm{MHz}, \mathrm{DMSO}-d_{6}\right) 1.80(3 \mathrm{H}, \mathrm{s}$, $\left.-\mathrm{C}(\mathrm{O}) \mathrm{CH}_{3}\right), 1.94\left(3 \mathrm{H}, \mathrm{s}-\mathrm{C}(\mathrm{O}) \mathrm{CH}_{3}\right), 1.96\left(3 \mathrm{H}, \mathrm{s},-\mathrm{C}(\mathrm{O}) \mathrm{CH}_{3}\right), 2.04\left(3 \mathrm{H}, \mathrm{s},-\mathrm{C}(\mathrm{O}) \mathrm{CH}_{3}\right), 3.87-4.01(3 \mathrm{H}, \mathrm{m}$, $\mathrm{H}-3^{\prime}, 5^{\prime}$ and $\left.\mathrm{H}-4^{\prime}\right), 3.95\left(3 \mathrm{H}, \mathrm{s},-\mathrm{OCH}_{3}\right), 4.86-5.00(2 \mathrm{H}, \mathrm{m}$, aliphatic), $5.39(1 \mathrm{H}, \mathrm{t}, J=9.9 \mathrm{~Hz}$, aliphatic), $5.80(1 \mathrm{H}, \mathrm{d}, J=8.1 \mathrm{~Hz}$, aliphatic), $7.33(1 \mathrm{H}, \mathrm{s} \mathrm{H}-8), 7.53-7.55(3 \mathrm{H}, \mathrm{m}), 8.06(2 \mathrm{H}, \mathrm{dd}, J=2.4 \mathrm{~Hz}$ and 9.3 $\left.\mathrm{Hz}, \mathrm{H}-2^{\prime}, 6^{\prime}\right), 8.32(1 \mathrm{H}, \mathrm{s}, \mathrm{H}-5) ;{ }^{13} \mathrm{C}\left(75 \mathrm{MHz}, \mathrm{DMSO}-d_{6}\right) 20.7,20.8,21.0,57.9,61.6,68.3,71.0,71.7,72.1$, 84.9, 98.5, 100.7, 119.1, 128.7, 129.3, 130.6, 131.4, 135.2, 136.1, 156.7, 157.0, 162.2, 162.7, 169.8, 169.9, 170.1, 171.6; HRMS $\left(\mathrm{ES}^{+}\right): \mathrm{m} / z[\mathrm{M}+\mathrm{H}]^{+}$calc for $\mathrm{C}_{30} \mathrm{H}_{30} \mathrm{O}_{13} \mathrm{I}: 725.0731$; found 725.0726.

2-(4-Fluorophenyl)-6-Iodo-7-methoxy-4H-chromen-4-one-3-O-2,3,4,6-O-tetraacetyl- $\beta$-d-glucopyranoside (2n): Brown solid (0.29 g, $79 \%$ ), $\mathrm{R}_{f}\left(50 \%\right.$ EtOAc-hexane) 0.65, m.p. 177-178 ${ }^{\circ} \mathrm{C} ; v_{\max }$ (ATR) 512, 525, 569, 650, 837, 1027, 1168, 1212, 1426, 1596, 1642, 1727, 2361, 2915, $3072 \mathrm{~cm}^{-1} ;{ }^{1} \mathrm{H}-\mathrm{NMR}$ (300 MHz, DMSO- $\left.d_{6}\right) 1.87$ $\left(3 \mathrm{H}, \mathrm{s},-\mathrm{C}(\mathrm{O}) \mathrm{CH}_{3}\right), 1.99\left(3 \mathrm{H}, \mathrm{s}-\mathrm{C}(\mathrm{O}) \mathrm{CH}_{3}\right), 2.01\left(3 \mathrm{H}, \mathrm{s},-\mathrm{C}(\mathrm{O}) \mathrm{CH}_{3}\right), 2.10\left(3 \mathrm{H}, \mathrm{s},-\mathrm{C}(\mathrm{O}) \mathrm{CH}_{3}\right), 3.62(1 \mathrm{H}, \mathrm{d}$, $J=9.3 \mathrm{~Hz}$, aliphatic), $3.89\left(3 \mathrm{H}, \mathrm{s},-\mathrm{OCH}_{3}\right) 3.95-3.97(2 \mathrm{H}, \mathrm{m}$, aliphatic), $5.07(1 \mathrm{H}, \mathrm{t}, J=8.1 \mathrm{~Hz}$, aliphatic), $5.17-5.31\left(2 \mathrm{H}, \mathrm{m}\right.$, aliphatic), $5.56(1 \mathrm{H}, \mathrm{d}, J=7.8 \mathrm{~Hz}$, aliphatic $), 7.00\left(2 \mathrm{H}, J_{\mathrm{HH}}=8.7\right.$ and $J_{\mathrm{HF}}=9.7 \mathrm{~Hz}$, $\left.\mathrm{H}-3^{\prime}, 5^{\prime \prime}\right), 7.20(1 \mathrm{H}, \mathrm{d}, J=7.5 \mathrm{~Hz}, \mathrm{H}-8), 8.00\left(2 \mathrm{H}, \mathrm{dd}, J_{\mathrm{HH}}=8.7 \mathrm{~Hz}\right.$ and $\left.J_{\mathrm{HF}}=5.4 \mathrm{~Hz}, \mathrm{H}-2^{\prime}, 6^{\prime}\right), 8.61(1 \mathrm{H}, \mathrm{d}$, $J=7.2 \mathrm{~Hz}, \mathrm{H}-5) ;{ }^{13} \mathrm{C}-\mathrm{NMR}\left(75 \mathrm{MHz}, \mathrm{DMSO}-d_{6}\right)$ 20.5, 20.6, 20.8, 55.4, 61.4, 68.2, 71.6, 71.7, 72.7, 77.8, 98.9, 
$104.8,105.1,116.4\left(\mathrm{~d},{ }^{2} J_{\mathrm{CF}}=21.8 \mathrm{~Hz}\right), 118.8,119.7,120.6,130.5\left(\mathrm{~d},{ }^{4} J_{\mathrm{CF}}=3.5 \mathrm{~Hz}\right), 130.9\left(\mathrm{~d},{ }^{3} J_{\mathrm{CF}}=8.0 \mathrm{~Hz}\right)$, $155.8,156.0,157.8,164.1\left(\mathrm{~d},{ }^{1} J_{\mathrm{CF}}=251.9 \mathrm{~Hz}\right), 169.5,169.9,170.1,170.3,171.7 ; \mathrm{HRMS}\left(\mathrm{ES}^{+}\right): \mathrm{m} / \mathrm{z}[\mathrm{M}+$ $\mathrm{H}]^{+}$calc for $\mathrm{C}_{30} \mathrm{H}_{29} \mathrm{O}_{13} \mathrm{FI}$ : 743.0637; found 743.0635.

2-(4-Chlorophenyl)-6-iodo-7-methoxy-4H-chromen-4-one-3-O-2,3,4,6-O-tetraacetyl- $\beta$-d-glucopyranoside (2o): Brown solid (0.27 g, 78\%), $\mathrm{R}_{f}\left(50 \%\right.$ EtOAc-hexane) 0.63, m.p. $184-185^{\circ} \mathrm{C} ; v_{\max }$ (ATR) $488,579,770$, 1030, 1164, 1200, 1420, 1633, 1750, 2651, 3070, $3071 \mathrm{~cm}^{-1}$; ${ }^{1} \mathrm{H}-\mathrm{NMR}(500 \mathrm{MHz}$, DMSO-d $) 1.80(3 \mathrm{H}, \mathrm{s}$, $\left.-\mathrm{C}(\mathrm{O}) \mathrm{CH}_{3}\right), 1.95\left(3 \mathrm{H}, \mathrm{s}-\mathrm{C}(\mathrm{O}) \mathrm{CH}_{3}\right), 1.96\left(3 \mathrm{H}, \mathrm{s},-\mathrm{C}(\mathrm{O}) \mathrm{CH}_{3}\right), 2.04\left(3 \mathrm{H}, \mathrm{s},-\mathrm{C}(\mathrm{O}) \mathrm{CH}_{3}\right), 3.82-4.00(3 \mathrm{H}, \mathrm{m}$, aliphatic), $3.84\left(3 \mathrm{H}, \mathrm{s},-\mathrm{OCH}_{3}\right), 4.93-5.04(2 \mathrm{H}, \mathrm{m}$, aliphatic), $5.39(1 \mathrm{H}, \mathrm{t}, J=9.5 \mathrm{~Hz}$, aliphatic), $5.76(1 \mathrm{H}$, $\mathrm{d}, J=7.5 \mathrm{~Hz}$, aliphatic), $7.01\left(2 \mathrm{H}, \mathrm{d}, J=9.0 \mathrm{~Hz}, \mathrm{H}-3^{\prime}, 5^{\prime}\right), 8.01\left(2 \mathrm{H}, \mathrm{d}, J=7.0 \mathrm{~Hz}, \mathrm{H}-2^{\prime}, 6^{\prime}\right), 8.10(1 \mathrm{H}, \mathrm{s}$ H-8), 8.43 (1H, s, H-5); ${ }^{13}$ C-NMR (125 MHz, DMSO-d $d_{6}$ ) 20.7, 20.8, 20.9, 57.9, 61.6, 68.3, 71.0, 71.8, 72.1, 84.9, 98.5, 100.7, 119.1, 128.1, 128.9, 130.4, 131.3, 134.2, 135.8, 156.7, 157.0, 162.2, 162.8, 169.8, 169.9, 170.1, 171.6; HRMS (ES ${ }^{+}$: $: m / z$ [M + H] $]^{+}$calc for $\mathrm{C}_{30} \mathrm{H}_{29} \mathrm{O}_{13}{ }^{35} \mathrm{ClI}$ : 759.0341; found 759.0336.

6-Iodo-7-methoxy-2-(4-methoxyphenyl)-4H-chromen-4-one-3-O-2,3,4,6-O-tetraacetyl- $\beta$-d-glucopyranoside (2p): Brown solid (0.30 g, 83\%), $\mathrm{R}_{f}\left(50 \%\right.$ EtOAc-hexane) 0.59 , m.p. $129-130^{\circ} \mathrm{C} ; v_{\max }$ (ATR) 482,568 , 777, 1029, 1151, 1213, 1416, 1630, 1753, 2641, 3068, $3072 \mathrm{~cm}^{-1}$; ${ }^{1} \mathrm{H}-\mathrm{NMR}(500 \mathrm{MHz}$, DMSO-d 6 ) 1.79 $\left(3 \mathrm{H}, \mathrm{s},-\mathrm{C}(\mathrm{O}) \mathrm{CH}_{3}\right), 2.02\left(3 \mathrm{H}, \mathrm{s}-\mathrm{C}(\mathrm{O}) \mathrm{CH}_{3}\right), 1.95\left(3 \mathrm{H}, \mathrm{s},-\mathrm{C}(\mathrm{O}) \mathrm{CH}_{3}\right), 1.96\left(3 \mathrm{H}, \mathrm{s},-\mathrm{C}(\mathrm{O}) \mathrm{CH}_{3}\right), 3.84(3 \mathrm{H}$, $\left.\mathrm{s},-\mathrm{OCH}_{3}\right), 3.86-3.94\left(3 \mathrm{H}, \mathrm{m}\right.$, aliphatic), $3.97\left(3 \mathrm{H}, \mathrm{s},-\mathrm{OCH}_{3}\right), 4.90-5.36(2 \mathrm{H}, \mathrm{m}$, aliphatic), $5.38(1 \mathrm{H}, \mathrm{t}$, $J=9.5 \mathrm{~Hz}$, aliphatic), $5.77\left(1 \mathrm{H}, \mathrm{d}, J=8.5 \mathrm{~Hz}\right.$, aliphatic), $7.10\left(2 \mathrm{H}, \mathrm{d}, J=9.0 \mathrm{~Hz}, \mathrm{H}-3^{\prime}, 5^{\prime}\right), 7.36(1 \mathrm{H}, \mathrm{s} \mathrm{H}-8)$, $8.01\left(2 \mathrm{H}, \mathrm{d}, J=8.5 \mathrm{~Hz}, \mathrm{H}-2^{\prime}, 6^{\prime}\right), 8.35(1 \mathrm{H}, \mathrm{s}, \mathrm{H}-5) ;{ }^{13} \mathrm{C}-\mathrm{NMR}\left(125 \mathrm{MHz}, \mathrm{DMSO}-d_{6}\right)$ 25.4, 25.5, 25.7, 39.6, 60.6, 62.7, 66.3, 70.1, 73.1, 75.0, 75.7, 76.7, 76.9, 89.3, 103.3, 105.5, 118.9, 119.1, 123.9, 127.5, 135.9, 140.1,

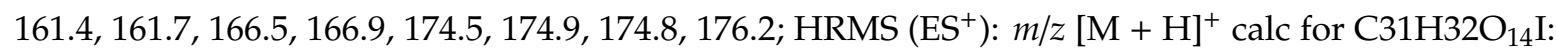
755.0837; found 755.0833 .

\subsection{In Vitro Cholinesterase ( $A C h E$ and BChE) Inhibition Assays}

Compounds 2a-2l were evaluated for anticholinesterase activities by the Ellman's method [36] with slight modification as described in previous investigations [22,37,38]. The absorbances were determined spectrometrically at $412 \mathrm{~nm}$ on a Varioskan flash spectrophotometer (Thermo Scientific, Waltham, MA, USA). The $\mathrm{IC}_{50}$ and standard deviation values were determined graphically using Graph Pad Prism.

\subsection{In Vitro $\beta$-Secretase Inhibitory Assays}

The inhibitory properties of compounds $\mathbf{2 a} \mathbf{a}-\mathbf{2 l}$ on $\beta$-secretase were evaluated by a fluorescence resonance energy transfer (FRET) assay (Pan Vera) with a recombinant baculovirus-expressed $\beta$-secretase and a specific substrate (Rh-EVNLDAEFK-Quencher) according to manufacturer instructions as described in our previous study [22]. The inhibition ratio was calculated using the following equation:

$$
\text { Inhibition }(\%)=\left[1-\left(\mathrm{S}-\mathrm{S}_{0}\right) /\left(\mathrm{C}-\mathrm{C}_{0}\right)\right] \times 100
$$

where $\mathrm{C}$ is the fluorescence of control (enzyme, assay buffer, and substrate) after $60 \mathrm{~min}$ of incubation, $\mathrm{C}_{0}$ is the fluorescence of control at time $0, \mathrm{~S}$ is the fluorescence of tested samples (enzyme, sample solution, and substrate) after $60 \mathrm{~min}$ of incubation, and $\mathrm{S}_{0}$ the fluorescence of the tested samples at time 0 .

\subsection{Kinetic Studies of $\mathbf{2} \mathbf{1}$ and $\mathbf{2} \mathbf{p}$ against ChEs and $\beta$-Secretase}

Kinetic evaluation of $\mathbf{2 l}$ and $\mathbf{2 p}$ against ChEs or $\beta$-secretase were conducted following similar procedures previously employed for the corresponding flavonol precursors [22]. Compounds $\mathbf{2 1}$ and $2 \mathbf{p}$ were selected for the kinetic studies with substrate concentrations ranging from $(0.1,0.5,2$. 5 , and $5 \mu \mathrm{M})$ and $(150,300$ and $450 \mathrm{nM})$ for ChEs or $\beta$-secretase, respectively. The Lineweaver-Burk plots (plots of the inverse of velocity $(1 / \mathrm{v})$ against the inverse of the substrate concentration $(1 /[\mathrm{S}])$ ) were 
used to ascertain the mode of inhibition of these compounds ( 21 and $2 \mathbf{p}$ ). On the other hand, the plots of $1 / v$ against concentration of inhibitor at each concentration of substrate (the Dixon plot) were used to determine their inhibitor constants (Ki).

\subsection{2,2-Diphenyl-1-picrylhydrazyl (DPPH) Radical Scavenging Activity Assay}

DPPH radical scavenging activity of compounds $\mathbf{2 e}, \mathbf{2 g}, \mathbf{2 i}, \mathbf{2 k}, \mathbf{2} \mathbf{1}, \mathbf{2 n}$, and $\mathbf{2 p}$ was evaluated following the literature method [39]. The compounds were evaluated against the natural antioxidants ascorbic acid (Sigma Aldrich, Saint Louis, MO, USA) and quercetin (Sigma Aldrich, Saint Louis, MO, USA) as positive controls. The test compounds at various concentration ranging from (0 to $40 \mu \mathrm{M})$ in DMSO were mixed with a solution of DPPH $(0.20 \mathrm{mM})$ in methanol. The mixtures were incubated in the dark for $45 \mathrm{~min}$ and the absorbances were recorded at $512 \mathrm{~nm}$ [40,41]. All tests and analyses were run in triplicate and averaged. The inhibition was calculated in terms of percentage using the formula below:

$$
\text { DPPH radical scavenged }(\%)=[(\mathrm{AbC}-\mathrm{AbS}) / \mathrm{AbC}] \times 100
$$

where $\mathrm{AbC}$ is absorbance of control and $\mathrm{AbS}$ the absorbance of the test sample. A graph of percentage inhibition of free-radical activity was plotted against concentration of the sample and the $\mathrm{IC}_{50}$ (compound concentration required to reduce the absorbance of the DPPH control solution by 50\%) was obtained from the graph.

\subsection{Molecular Docking}

The CDOCKER module of Discovery Studio software (version 17.1.0.16143, Accelrys, San Diego, CA, USA) was used to investigate interactions of the title compounds with AChE, BChE and $\beta$-secretase. PDB structures used were as follows: for AChE was 1GQR; for BChE was 1P0I and for $\beta$-Secretase was 3IXJ. The proteins structures were prepared prior to docking using default settings of Discovery Studio except that co-crystalized ligands were removed. The compounds were drawn in Discovery Studio then prepared using default parameters prior to docking. The binding sites used to dock compounds represented co-crystalized ligand or substrate locations as identified by Discovery Studio software, the grid box centered at the geometrical center of the region of the co-crystallized ligand binding sphere. In instances where docking failed for the default sphere size, the radius of the docking sphere increased without affecting the grid box center and docking conducted to achieve results. The sphere size increased from 11.1 to 11.8 for 1GQR; from 12 to 14.2 for P0I and from 15.3 to 16.5 for 3IXJ. The best scoring pose without unfavorable interactions was selected and represented as 2D plots using Discovery Studio.

\section{Conclusions}

Compounds $\mathbf{2 l}$ and $\mathbf{2 p}$, which have potential to exhibit dual inhibitory effect against AChE and $\mathrm{BChE}$ activities, were found to exhibit moderate inhibitory activity against $\beta$-secretase. Molecular docking studies of these compounds into $\mathrm{AChE}, \mathrm{BChE}$, and $\beta$-secretase binding sites predicted electrostatic and hydrophobic interactions to be the key factors that stabilize the enzyme-ligand complexes. The observed non-competitive inhibitory mode of compounds 21 and $2 \mathbf{p}$ confirmed by the kinetic studies against AChE activity indicates that the predicted interactions of these compounds with protein residues in the CAS and PAS do not exclude substrate binding. Docking of compounds 21 and $2 p$ into $\beta$-secretase, on the other hand, showed no interaction with the catalytic aspartic acids Asp32 and Asp228. This prediction is consistent with the kinetic results indicating binding to the enzyme at sites affecting allosteric changes that decrease activity rather than competing with the substrate to bind the active site. The observed anticholinesterase activity and moderate free-radical scavenging potential of the $O$-glucopyranoside derivative $2 \mathbf{p}$ demonstrate the significance of the liphophilic methoxy group on both ring-A and ring-B. Since methoxy-substituted flavonols and their 
glycosides are widely distributed in natural foods, these results provide important information for the evaluation of the role of a flavonoid-rich diet for the prevention of AD.

Supplementary Materials: The following are available online. Copies of 1H- and 13C-NMR spectra of compounds $\mathbf{2 a - 2 p}$ (Figure S1); and the Lineweaver-Burk and Dixon plots for $\mathbf{2 l}$ and $\mathbf{2 p}$ against AChE and BChE (Figure S2) and against $\beta$-secretase (Figure S3).

Author Contributions: E.N.A. carried out the synthesis, acquired and analyzed the spectral data and performed the enzyme assays under the supervision of S.G. The latter performed molecular docking and contributed in the interpretation of the corresponding data. M.J.M conceptualized the project, reviewed the literature, and interpreted the data and results. Both S.G. and M.J.M. wrote the manuscript.

Funding: This project was funded by the University of South Africa and the National Research Foundation (GUN: 118554).

Acknowledgments: We thank the University of Stellenbosch Central Analytical Facility (CAF) and the University of the Witwatersrand for mass spectrometric and X-ray analyses, respectively.

Conflicts of Interest: The authors declare no conflict of interest.

\section{References}

1. Hui-Ming, G.; Jau-Shyong, H. Why neurodegenerative diseases are progressive: Uncontrolled inflammation drives disease progression. Trends Immunol. 2008, 29, 357-365.

2. Ortiz, G.G.; Moisés, F.P.P.; Mireles-Ramírez, M.; Flores-Alvarado, L.J.; González-Usigli, H.; Sánchez-González, V.J.; Rivero-Moragrega, P. Oxidative stress: Love and hate history in central nervous system. Adv. Protein Chem. Struct. Biol. 2017, 108,1-31.

3. Marco-Contelles, J.; Unzeta, M.; Bolea, I.; Esteban, G.; Ramsay, R.R.; Romero, A.; Martinez-Murillo, R.; Carreiras, M.C.; Ismaili, L. Ass234, as a new multi-target directed propargylamine for Alzheimer's disease therapy. Front. Neurosci. 2016, 10, 294. [CrossRef]

4. Gocer, H.; Topal, F.; Topal, M.; Küçük, M.; Teke, D.; Gulcin, I.; Alwasel, S.H.; Supuran, C.T. Acetylcholinesterase and carbonic anhydrase isoenzymes I and II inhibition profiles of taxifolin. J. Enzym. Inhib. Med. Chem. 2016, 31, 441-447. [CrossRef]

5. Verdile, G.; Fuller, S.J.; Martins, R.N. The role of type 2 diabetes in neurodegeneration. Neurobiol. Dis. 2015, 84, 22-38. [CrossRef] [PubMed]

6. Kan, M.J.; Lee, J.E.; Wilson, J.G.; Everhart, A.L.; Brown, C.M.; Hoofnagle, A.N.; Jansen, M.; Vitek, M.P.; Gunn, M.D.; Colton, C.A. Arginine deprivation and immune suppression in a mouse model of Alzheimer's disease. J. Neurosci. 2015, 35, 5969-5982. [CrossRef] [PubMed]

7. Christen, Y. Oxidative stress and Alzheimer disease. Am. J. Clin. Nutr. 2000, 71, 621S-629S. [CrossRef]

8. Huang, W.-J.; Zhang, X.; Chen, W.-W. Role of oxidative stress in Alzheimer's disease. Biomed. Rep. 2016, 4, 519-522. [CrossRef]

9. Morphy, R.; Rankovic, Z. Designed multiple ligands. An emerging drug discovery paradigm. J. Med. Chem. 2005, 48, 6523-6543. [PubMed]

10. Bajda, M.; Guzior, N.; Ignasik, M.; Malawska, B. Multi-target-directed ligands in Alzheimer's disease treatment. Curr. Med. Chem. 2011, 18, 4949-4975. [CrossRef]

11. Chen, X.; Decker, M. Multi-target compounds acting in the central nervous system designed from natural products. Curr. Med. Chem. 2013, 20, 1673-1685. [CrossRef] [PubMed]

12. Williams, R.J.; Spencer, J.P.E. Flavonoids, cognition, and dementia: Actions, mechanisms, and potential therapeuticutility for Alzheimer disease. Free Rad. Biol. Med. 2012, 52, 35-45. [CrossRef] [PubMed]

13. Shimmyo, Y.; Kihara, T.; Akaike, A.; Niidome, T.; Sugimoto, H. Flavonols and flavones as BACE-1 inhibitors: Structure-activity relationship in cell-free, cellbased and in silico studies reveal novel pharmacophore features. Biochim. Biophys. Acta 2008, 1780, 819-825. [CrossRef] [PubMed]

14. Luisa Helena, C.; Leila, Z.; Elga Heloisa, A.; Maria Santos Reis Bonorino, F.; Poliane, F.; Rosangela Guollo, D.; Moacir Geraldo, P.; Fatima Regina Mena Barreto, S. Flavonoids: Prospective Drug Candidates. Mini-Rev. Med. Chem. 2008, 8, 1429-1440.

15. Hayes, M.R.; Pietruszka, J. Synthesis of glycosides by glycosynthases. Molecules 2017, 22, 1434. [CrossRef] 
16. Guzzi, C.; Colombo, L.; De Luigie, A.; Salmona, M.; Nicotra, F.; Airoldi, C. Flavonoids and their glycosides as anti-amyloidogenic compounds: Ab1-42 interaction studies to gain new insights into their potential for Alzheimer's disease prevention and therapy. Chem. Asian. J. 2017, 12, 67-75. [CrossRef]

17. Rahman, A.; Ali, M.T.; Shawan, M.M.A.K.; Sarwar, M.G.; Khan, M.A.K.; Halim, M.A. Halogen-directed drug design for Alzheimer's disease: A combined density functional and molecular docking study. SpringerPlus 2016, 5, 1346-1359. [CrossRef]

18. Lu, Y.; Shi, T.; Wang, Y.; Yang, H.; Yan, X.; Luo, X.; Jiang, H.; Zhu, W. Halogen bonding- A novel interaction for rational drug design? J. Med. Chem. 2009, 52, 2854-2862. [CrossRef]

19. Lu, Y.; Liu, Y.; Xu, Z.; Li, H.; Liu, H.; Zhu, W. Halogen bonding for rational drug design and new drug discovery. Expert Opin. Drug Discov. 2012, 7, 375-383. [CrossRef]

20. Wilcken, R.; Zimmermann, M.O.; Lange, A.; Joerger, A.C.; Boeckler, F.M. Principles and applications of halogen bonding in medicinal chemistry and chemical biology. J. Med. Chem. 2012, 56, 1363-1388. [CrossRef]

21. Mughal, E.U.; Javid, A.; Sadiq, A.; Murtaza, S.; Zafar, M.N.; Khan, B.A.; Sumra, S.H.; Tahir, M.N.; Kanwal; Khan, K.M. Synthesis, structure-activity relationship and molecular docking studies of 3-O-flavonol glycosides as cholinesterase inhibitors. Bioorg. Med. Chem. 2018, 26, 3696-3706.

22. Mphahlele, M.J.; Agbo, E.N.; Gildenhuys, S. Synthesis and evaluation of the 4-substituted 2-hydroxy-5-iodochalcones and their 7-substituted 6-iodoflavonol derivatives for inhibitory effect on cholinesterases and $\beta$-secretase. Int. J. Mol. Sci. 2018, 19, 4112. [CrossRef] [PubMed]

23. CCDC 1915892 Contains the Supplementary Crystallographic Data for This Paper. These Data Can Be Obtained Free of Charge from The Cambridge Crystallographic Data Centre. Available online: www.ccdc. cam.ac.uk/data_request/cif (accessed on 18 September 2019).

24. Hopkins, A.L.; Groom, C.R. The druggable genome. Nat. Rev. Drug Discov. 2002, 1, 727-730. [CrossRef] [PubMed]

25. Ballard, C.G. Advances in the treatment of Alzheimer's disease: Benefits of dual cholinesterase inhibition. Eur. Neurol. 2002, 47, 64-70. [CrossRef] [PubMed]

26. Garcia-Ayllon, M.S.; Small, D.H.; Avila, J.; Saez-Valero, J. Revisiting the role of acetylcholinesterase in Alzheimer's disease: Cross-talk with P.-tau and $\beta$-amyloid. Front. Mol. Neurosci. 2011, 22, 1-9.

27. Guillozet, A.L.; Smiley, J.F.; Mash, D.C.; Mesulam, M.-M.C. Butyrycholinesterase in the life cycle of amyloid plaques. Ann. Neurol. 1997, 42, 909-918. [CrossRef] [PubMed]

28. Youn, K.; Park, J.-H.; Lee, J.; Jeong, W.-S.; Ho, C.-T.; Jun, M. The identification of biochanin A as a potent and selective $\beta$-site app-cleaving enzyme 1 (Bace1) inhibitor. Nutrients 2016, 8, 637. [CrossRef]

29. Kang, J.E.; Cho, J.K.; Curtis-Long, M.J.; Ryu, H.W.; Kim, J.H.; Kim, H.J.; Yuk, H.K.; Kim, D.W.; Park, K.H. Inhibitory evaluation of sulfonamide chalcones on $\beta$-secretase and acylcholinesterase. Molecules 2013, 18, 140-153. [CrossRef]

30. Ansari, M.A.; Abdul, H.M.; Joshi, G.; Opii, W.O.; Butterfield, D.A. Protective effect of quercetin in primary neurons against $\alpha, \beta(1-42)$ : Relevance to Alzheimer's disease. J. Nutr. Biochem. 2009, 20, 269-275. [CrossRef]

31. Wang, J.; Wang, Z.M.; Li, X.M.; Li, F.; Wu, J.-J.; Kong, L.-Y.; Wang, X.-B. Synthesis and evaluation of multi-target-directed ligands for the treatment of Alzheimer's disease based on the fusion of donepezil and melatonin. Bioorg. Med. Chem. 2016, 24, 4324-4338. [CrossRef]

32. Nicolet, Y.; Lockridge, O.; Masson, P.; Fontecilla-Camps, J.C.; Nachon, F. Crystal structure of human butyrylcholinesterase and of its complexes with substrate and products. J. Biol. Chem. 2003, 278, 41141-41147. [CrossRef] [PubMed]

33. Maia, M.A.; Sousa, E. Bace-1 and $\gamma$-secretase as therapeutic targets for Alzheimer's disease. Pharmaceuticals 2019, 12, 41. [CrossRef] [PubMed]

34. Butini, S.; Brogi, S.; Novellino, E.; Campiani, G.; Ghosh, A.K.; Brindisi, M.; Gemma, S. The structural evolution of $\beta$-secretase inhibitors: A focus on the development of small-molecule inhibitors. Curr. Top. Med. Chem. 2013, 13, 1787-1807.

35. Yadav, P.; Parshad, B.; Manchanda, P.; Sharma, S. Chromones and their derivatives as radical scavengers: A remedy for cell impairment. Curr. Top. Med. Chem. 2004, 14, 2552-2575. [CrossRef] [PubMed]

36. Heo, H.J.; Lee, C.Y. Protective effects of quercetin and vitamin C against oxidative stress-induced neurodegeneration. J. Agric. Food Chem. 2004, 52, 7514-7517. [CrossRef] 
37. Arduini, F.; Errico, I.; Amine, A.; Micheli, L.; Palleschi, G.; Moscone, D. Enzymatic spectrophotometric method for aflatoxin B detection based on acetylcholinesterase inhibition. Anal. Chem. 2007, 79, 3409-3415. [CrossRef] [PubMed]

38. Akıncıoğlu, K.; Akıncıoğlu, H.; Gülcin, í; Durdagi, S.; Supuran, C.T.; Suleyman, G. Discovery of potent carbonic anhydrase and acetylcholine esterase inhibitors: Novel sulfamoylcarbamates and sulfamides derived from acetophenones. Bioorg. Med. Chem. 2015, 23, 3592-3602. [CrossRef]

39. Zhu, K.; Zhou, H.; Qian, H. Antioxidant and free radical scavenging activities of wheat germ protein hydrolysates (WGPH) prepared with alcalase. Process Biochem. 2006, 41, 1296-1302. [CrossRef]

40. Köse, L.P.; Gülcin, I.; Gören, A.C.; Namiesnik, J.; Martinez-Ayala, A.L.; Gorinstein, S. LC-MS/MS analysis, antioxidant and anticholinergic properties of galanga (Alpinia officinarum Hance) rhizomes. Ind. Crops Prod. 2015, 74, 712-721. [CrossRef]

41. Topal, F.; Nar, M.; Gocer, H.; Kalin, P.; Kocyigit, U.M.; Güçlcin, I.; Alwasel, S.H. Antioxidant activity of taxifolin: An activity-structure relationship. J. Enzyme Inhib. Med. Chem. 2016, 31, 674-683.

Sample Availability: Samples of the compounds $\mathbf{2 a}-\mathbf{2} \mathbf{p}$ are available from the authors.

(C) 2019 by the authors. Licensee MDPI, Basel, Switzerland. This article is an open access article distributed under the terms and conditions of the Creative Commons Attribution (CC BY) license (http://creativecommons.org/licenses/by/4.0/). 